\title{
Figure bjelina
}

Sažetak: Stilistika i retorika oduvijek pomalo zanemaruju stilogene postupke povezane s razinom zapisa jezične poruke, a postupci koji se temelje na manipuliranju razmacima između riječi periferna su tema čak i u jednom od najelaboriranijih pregleda pismovnih figura, onome njemačkoga retoričara H. F. Pletta, koji inače prikazuje mnoštvo postupaka koji se temelje na poigravanju grafemima (ili grafovima), interpunkcijskim i pravopisnim znakovima. Metoda ovoga istraživanja inspirirat će se upravo Plettom, koji grafemske figure (kako on naziva postupke koje mi nazivamo figurama zapisa ili pismovnim figurama) dijeli i definira pomoću operacija adicije, suptrakcije, permutacije, supstitucije i ekvivalencije pojedinih elemenata zapisa. Prema tim operacijama ustanovit će se i oprimjeriti pet podtipova tih figura: adicijske, suptrakcijske, permutacijske, supstitucijske i ekvivalencijske figure bjelina, ovisno o tome modificira li se kakav konvencionalan zapis dodavanjem, izostavljanjem ili premještanjem bjelina, zamjenom bjelina kakvim drugim pismovnim sredstvima, odnosno o tome pokazuje li se kakva ekvivalencija među postupcima manipuliranja razmacima između riječi unutar kakvoga zapisa. Korpus se sastoji od primjera iz hrvatskog reklamnog, novinarskog i književnog diskursa, ali uključit će zapise i iz drugih konteksta da bi se uputilo na sveprisutnost tih postupaka u suvremenoj kulturi.

Ključne riječi: grafostilistika, figure zapisa, figure bjelina

Figurama bjelina nazivamo tip figura zapisa u kojem je uočljivo intencionalno poigravanje pravilima o sastavljenom i nesastavljenom pisanju riječi. Figure zapisa definiramo pak kao intencionalna očuđenja zapisa jezične poruke, proizvedenog da usredotoči pozornost recipijenta i deautomatizira njegovu percepciju pisane poruke. Dio figura zapisa temelji se na devijaciji od (orto)grafijskih pravila ili od stilističkog ko(n)teksta (adicijske, suptrakcijske, permutacijske i supstitucijske figure), a dio na ostvarivanju kakvog tipa ekvivalencije u zapisu, bez obzira na poštivanje ili narušavanje pravopisne norme (ekvivalencijske figure). 
Te figure, koje se inače nazivaju i grafostilemima ili grafostilističkim postupcima, jedan su od ključnih predmeta grafostilistike, stilističke discipline čiji su predmet pretežno intencionalna očuđenja zapisa jezične poruke na razini slovnog sastava i grafije, interpunkcije i uporabe ostalih pravopisnih znakova. ${ }^{1}$

Figure bjelina možemo smatrati perifernim područjem iz više perspektiva. Retorika se rijetko bavi začudnim pismovnim fenomenima. Iznimke su neki postupci koji se obično uvrštavaju među figure dikcije, a koji bi se vjerojatno bolje okarakterizirali kao figure zapisa, poput dijela anagrama, palindroma, akrostiha i dr. ${ }^{2}$ Rijetki retoričari posvećuju im jednaku pozornost kao figurama koje se temelje na poigravanju na drugim jezičnim razinama. Jedan je od njih H. F. Plett, koji grafemske figure stavlja uz bok fonološkima, morfološkima, sintaktičkima, semantičkima i tekstološkima, no i u njegovu pregledu postupci poigravanja bjelinama posve su marginalni. ${ }^{3}$ Stilističarima su pak nerijetko zanimljiviji interpunkcijski grafostilemi, ${ }^{4}$ kao i oni koji se temelje na poigravanju slovima. ${ }^{5}$

Pristupi li se međutim začudnim poigravanjima pravilima o sastavljenom i nesastavljenom pisanju po istim načelima kao i poigravanju slovima (grafovima) i interpunkcijskim znakovima, razmatrajući postoje li mogućnosti, a potom, dakako, i realizacije tih poigravanja operacijama dodavanja, izostavljanja, premetanja i zamjenjivanja bjelina, kao i kakva jednakovrijednost u njihovoj raspoređenosti unutar kakvog diskursa, ${ }^{6}$ ispostavlja se da i u tom području postoji pet podtipova figura - adicijske, suptrakcijske, permutacijske, supstitucijske i ekvivalencijske figure bjelina - te da je broj njihovih varijacija prilično velik. ${ }^{7}$ Velik je

\footnotetext{
${ }^{1}$ Nikola Košćak, „Uvod u grafostilistiku. Figure zapisa,“ skripta (Filozofski fakultet Sveučilišta u Zagrebu, 2018), 10.

${ }^{2}$ Usp. Krešimir Bagić, Rječnik stilskih figura (Zagreb: Školska knjiga, 2012).

${ }^{3}$ Bjeline i neki postupci u vezi s njima spominju se u Heinrich F. Plett, Literary Rhetoric. Concepts - Structures - Analyses (Leiden - Boston: Brill, 2010), 254-255.

${ }^{4}$ Usp. Krunoslav Pranjić, „Stil i stilistika,“ u Uvod u književnost: teorija, metodologija, ur. Zdenko Škreb i Ante Stamać (Zagreb: Nakladni zavod Globus, 1983), 253-302.

${ }^{5}$ Usp. Marina Katnić-Bakaršić, Stilistika (Sarajevo: Ljiljan, 2007).

${ }^{6}$ Operacije kojima smo podijelili područje ovih pismovnih fenomena preuzete su iz Heinrich F. Plett, Textwissenschaft und Textanalyse: Semiotik, Linguistik, Rhetorik (Grundlagen der Sprachdidaktik) (Heidelberg: Quelle \& Meyer, 1975) i Heinrich F. Plett, Literary Rhetoric. Concepts - Structures - Analyses (Leiden - Boston: Brill, 2010).

${ }^{7}$ Broj varijacija figura bjelina ipak ne dostiže onaj figura slova, u što je moguće uvjeriti se već i letimičnom usporedbom s tipologijom potonjih u Nikola Košćak, „Figure slova,“ u XII. međunarodni kroatistički znanstveni skup. Zbornik radova, ur. Stjepan Blažetin (Pečuh: Znanstveni zavod Hrvata u Madžarskoj, 2015), 403-427.
} 
također i broj njihovih realizacija, uvelike zahvaljujući njihovu bujanju u neknjiževnim kontekstima kao što su reklame (logotipi, plakati), društvene mreže (memovi) i popularna kultura (naslovnice albuma, grafiti) posljednjih desetljeća. Drugim riječima, ispostavlja se da bi figure bjelina, koje se na prvi pogled mogu činiti posve perifernim fenomenom, zapravo mogle biti jedan od središnjih predmeta interesa grafostilistike kao stilističke discipline, kao i retorike koja svoj interes proširuje na pismovni plan jezičnih poruka, a da tome tako nije i zbog toga što se radi o fenomenima koji se ne pojavljuju često u povlaštenim diskursima tih disciplina (osobito književnom), a i pojavljuju se tek odnedavno (barem u usporedbi s drugim stilskim figurama) u većem broju (varijacija).

S obzirom na to da se u Matičinu Pravopisu bjelina (prazno mjesto među riječima) određuje kao pravopisni znak u osobitom smislu, ${ }^{8}$ odnosno napominje se da se radi o grafičkom sredstvu koje ima ulogu sličnu ulozi pravopisnih znakova, ${ }^{9}$ figure bjelina mogle bi se prikazati i u tekstu posvećenom figurama pravopisnih znakova. Ipak, s obzirom na to da bjeline imaju osobitu funkciju u zapisu po kojoj se razlikuju od (svih drugih) pravopisnih znakova (naime rastavljanje riječi), kao i na to da po brojnosti svojih varijacija uvelike nadmašuju sve ostale figure

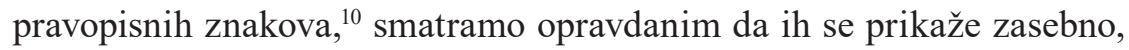
pa čak i utvrdi kao poseban tip figura zapisa.

\section{Adicijske figure bjelina}

Adicijske figure bjelina ostvaruju se kao intencionalna rastavljanja grafičke cjeline riječi bjelinom (ili bjelinama).

Jednim dijelom takva se rastavljanja mogu, doduše, percipirati i kao sporadična spacioniranja slova ${ }^{11}$ unutar zapisa koje riječi ili više njih, primjerice ona koja predstavljaju tek tipografska poigravanja bez evidentne znakovitosti (motiviranosti) koja bi proizlazila iz relacije toga pismovnoga postupka s jezičnom porukom ili kontekstom. Takva dekorativna umetanja bjelina unutar riječi (ili sporadična spacioniranja slova unutar riječi) uočavamo primjerice na naslovnici albuma

\footnotetext{
${ }^{8}$ Lada Badurina, Ivan Marković, i Krešimir Mićanović, Hrvatski pravopis (Zagreb: Matica hrvatska, 2007), 93.

${ }_{9}$ Badurina, Marković, i Mićanović, Hrvatski pravopis, 112.

${ }^{10}$ Usp. Košćak, „Uvod u grafostilistiku. Figure zapisa.“

${ }^{11}$ Ta nas dilema podsjeća da bismo trebali razlikovati razmak između riječi (bjelinu) i razmak između slova (spacioniranje slova).
} 
Heligoland britanskog benda Massive Attack i na naslovnici albuma Live 2015 hrvatskog benda Urban \& 4 (na kojoj se kombiniraju s nekonvencionalnim prenošenjima dijela riječi u novi redak) te na plakatu za kazališnu predstavu Olivera Frljića Naše nasilje $i$ vaše nasilje:
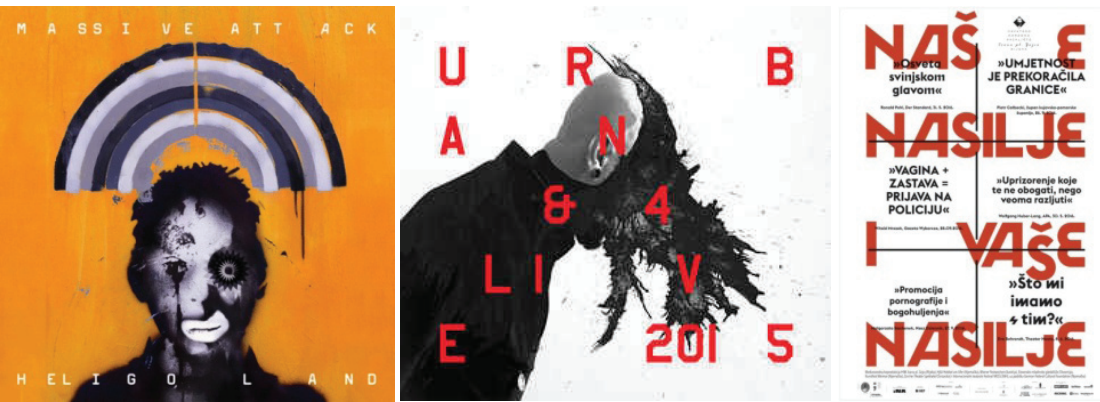

Slika 1. Naslovnica albuma Heli-Slika 2. Naslovnica albuma Live 2015 Slika 3. Plakat za goland glazbenog sastava Massive glazbenog sastava Urban \& 4. Fot. kazališnu predstavu Attack. Fot. N. Košćak

N. Košćak

Olivera Frljića Naše nasilje $i$ vaše nasilje. https://hnk-zajc.hr/en/ predstava/our-violenceand-your-violence/

Katkad međutim epenteze bjelina unutar riječi (ili sporadična spacioniranja) evidentno jesu u kakvoj relaciji sa značenjem jezične poruke koju prenosi zapis ili s kontekstom. Takvi razmaci primjerice mogu se doimati metaforama protežnosti, osamljenosti i sl. Tako u zapisu naslova zbornika Prostori snova urednica Žive Benčić i Dunje Fališevac razmaci unutar riječi metaforički reprezentiraju prostore na koje se referira naslovom, a u zapisu naslova zbornika Devijacije i promašaji: Etnografija domaćeg socijalizma urednica Lade Čale Feldman i Ines Prica umetnuta bjelina unutar zapisa riječi devijacija predstavlja metaforu devijacije. Na plakatu pak Filmskih mutacija - Festivala nevidljivog filma „suvišne“ se bjeline mogu tumačiti kao metafora nevidljivosti prezentiranih filmova. Intencionalnost, pa stoga i figurativnost, višestrukog razmicanja slova $\langle\mathrm{E}\rangle$ od ostatka riječi u ludičkom zapisu Playboyeva kolumnista Roberta Carole $\langle$ ALON E $\rangle$ lako se detektira jer postupak se ekspresno percipira kao metafora osamljenosti kojom zapis upućuje na samo značenje izraza alone ('sam'). ${ }^{12}$

\footnotetext{
${ }^{12}$ Slična je metaforika bjelina prisutna i kod zapisa u kojima se slova supstituiraju bjelinama - npr. <m ss ng $>-$ koje su nalik ovima, no ipak su drugoga tipa. Radi se naime o figurama slova, a ne bjelina, jer pri određivanju tipa (supstitucijske) figure zapisa odlučujuće je koji se element pisma zamjenjuje, a ne čime se to čini.
} 

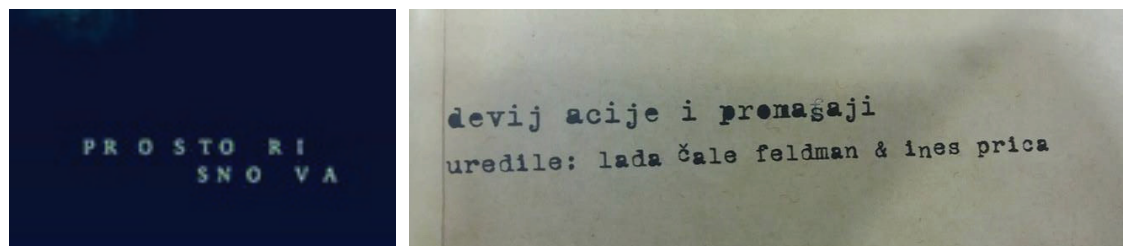

Slika 4. Naslovnica knjige Pro- Slika 5. Naslovnica knjige Devijacije i promašaji: Etnografija stori snova urednica Žive Benčić domaćeg socijalizma urednica Lade Čale Feldman i Ines Prica i Dunje Fališevac (detalj). Fot. (detalj). Fot. N. Košćak

N. Košćak

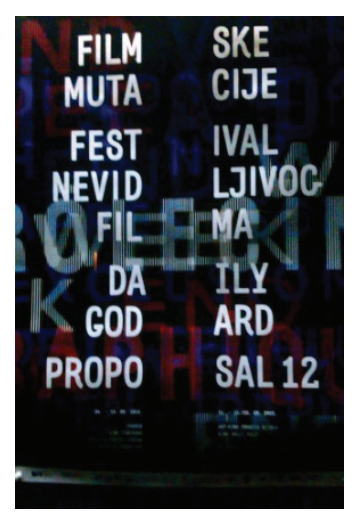

Slika 6. Plakat za Filmske mutacije - Festival nevidljivog filma. www.facebook.com

\section{ALON E}

Slika 7. Ilustracija Roberta Carole. www.playboy.com

Umetanjem bjelina unutar zapisa pojedine riječi ili izraza katkad se potonji „pretvaraju“ u bliskozvučni izraz, koji se, dakako, sastoji od većeg broja riječi. Taj se tip adicijskih figura bjelina temelji na djelomičnoj homografiji i homonimiji. Postupak kojim se jedna riječ tako morfološki nemotivirano rastavlja na manje jedinice često se primjenjivao u naslovima Feral Tribunea: ${ }^{13}$

- BU DALA (FT 565: 47)

- DI JE REZA (FT 567: 47)

- DOKTOR AT (FT 1998)

- ALI BI (FT 1997)

- RUŽ MARIN (FT 2000)

- PUKOV NIK (FT 564: 47)

- KOS I LICA (FT 1997)

- DNEVNI K (FT 1998)

${ }^{13}$ Zbog nedostupnosti preciznih podataka o broju novina i stranici uz pojedine naslove navodimo tek godinu objavljivanja. 
- SVE ĆE NIK (FT 1998)

- PLAV UŠA (FT 1998)

- NAZIV NIK (FT 1999)

- STA DI ON (FT 1999)

- POLI CAJKA (FT 1999)

- PAS I JA (FT 2000)

- KOŠ ULJA (FT 2000)

- VOJNI K (FT 2000)

- TRI BUNE (FT 2000)

- RAK I JA (FT 2000)

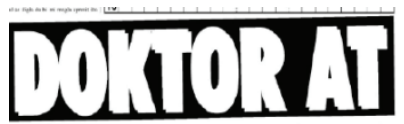

Slika 8. Feral Tribune (1998)

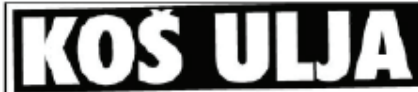

Slika 9. Feral Tribune (2000)

Primjere toga tipa nalazimo i u zapisu naslova 〈HAJD' U K.... $\mathrm{s}$ jednog bloga $\mathrm{s}$ vicevima na temu splitskog nogometnog kluba Hajduk $;^{14} \mathrm{u}$ natpisima $\langle$ PUN K.〉 i $\langle$ PUT IN.〉, uz asocijacije na punk i na prezime predsjednika Ruske Federacije Vladimira Putina, na plakatima srbijanskog dizajnera Nikole Puzigaće; u mетu s bivšim ministrom poljoprivrede Petrom Čobankovićem koji se poigrava relativnom homografijom i homofonijom riječi orangutan i regionalnog izraza oran gutan; u mетu s pokojnom glumicom Annom Nicole Smith i njezinim suprugom J. Howardom Marshallom koji se poigravanjem djelomičnom homografijom imenice animatori i izraza Ani matori 'Ani stari' šali na račun razlike u njihovim godinama; u memu s glumicom Angelinom Jolie koji u sličnu jednadžbu uključuje i grafodomesticiranje stranog imena $\mathrm{i} \mathrm{dr}$.

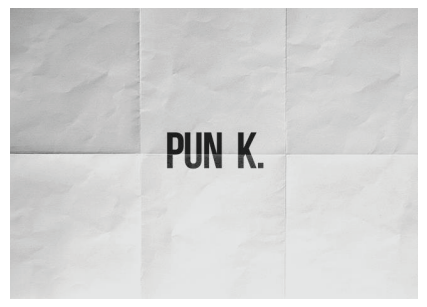

Slika 10. Plakat Nikole Puzigaće. www.facebook.com

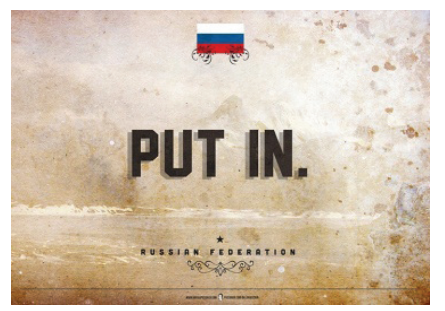

Slika 11. Plakat Nikole Puzigaće. www.facebook.com

\footnotetext{
${ }^{14}$ http://blog.dnevnik.hr/narodnapolitika/2011/10/1629555103/hajd-u-k-3-najbolja-vica-ohajduku-ikad.html (9. travnja 2020).
} 


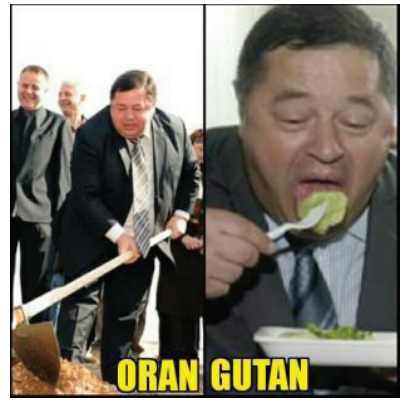

Slika 12. Meme. www.facebook.com

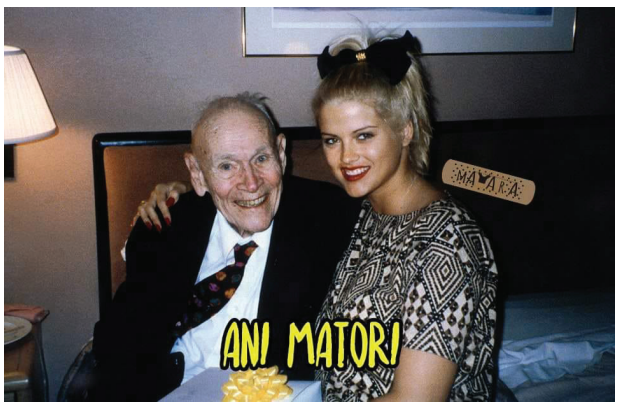

Slika 13. Meme. www.facebook.com

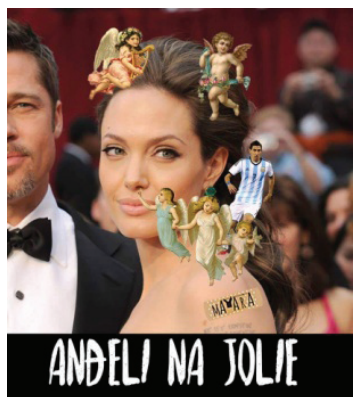

Slika 14. Meme. www.facebook.com

Nekoliko primjera donosi i Rebeka Holjevac u tekstu Grafostilistika digitalnog diskursa, između ostalog i adiciju bjelina

u funkciji komentiranja aktualnih političkih zbivanja. Tako je na dan kada je bivši predsjednik Republike Srpske Radovan Karadžić osuđen na 40 godina zatvora zbog ratnih zločina objavljen post na stranici Di su pare? u kojem se adicijom bjeline unutar imena Radovan dobio izraz rado van te se na taj način prikazala ironija u njegovoj situaciji s obzirom na to da je dobio kaznu od 40 godina „unutra“. 15

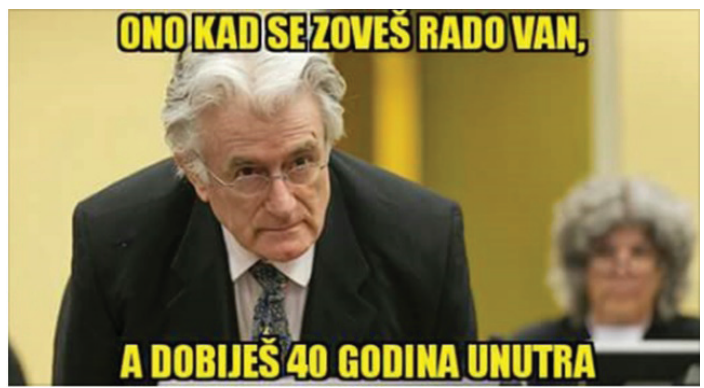

Slika 15. Meme. www.facebook.com

${ }^{15}$ Rebeka Holjevac, „Grafostilistika digitalnog diskursa,“ 27. siječnja 2017, pristupljeno 8. kolovoza 2020, http://stilistika.org/studentski-kutak/diplomski-radovi/grafostilistika-digitalnog-diskursa. 
Primjer takvog tipa adicijske figure bjelina nalazimo i u sloganu Say goodbye to Middle tones za Kodakov printer, u reklami objavljenoj u vrijeme vjenčanja princa Williama i Kate Middletone. Zahvaljujući popratnoj slici s tog vjenčanja, bliskozvučnosti sintagme middle tones i oblika prezimena Middletone te adiciji bjeline unutar zapisa riječi Middletones, slogan je dvoznačan te se čita i kao Say goodbye to Middletones 'reci zbogom Middletonima' (dakako, uz referencu na mladino napuštanje dosadašnje obitelji) i kao Say goodbye to middle tones 'reci zbogom srednjim tonovima' (uz referencu na kvalitetu ispisa).

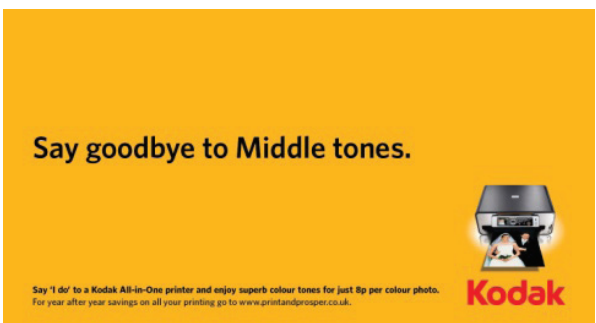

Slika 16. Reklama za pisače Kodak. http://adsoftheworld. com/media/print/kodak_inkjet_printers_royal_wedding_3

Jedan je od uspjelijih primjera „pretvaranja“ riječi u novi izraz umetanjem bjelina poznata karikatura koja se poigrava anitetičnošću bliskozvučnih i (gotovo) homografnih izraza psychotherapist 'psihoterapeut' i psycho the rapist 'psihopat silovatelj'. Slično je inspiriran i meme s predsjednikom Republike Srbije Aleksandrom Vučićem u kojem se riječ psihodelija „rastavlja“ u izraz psiho Delija (asocijacija na Delije, navijače beogradskog nogometnog kluba Crvena Zvezda).

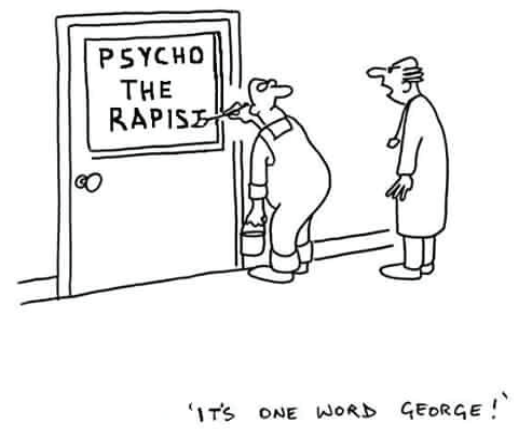

Slika 17. Karikatura nepoznata autora. https:// shareitsfunny.com/psycho-the-rapist-2/

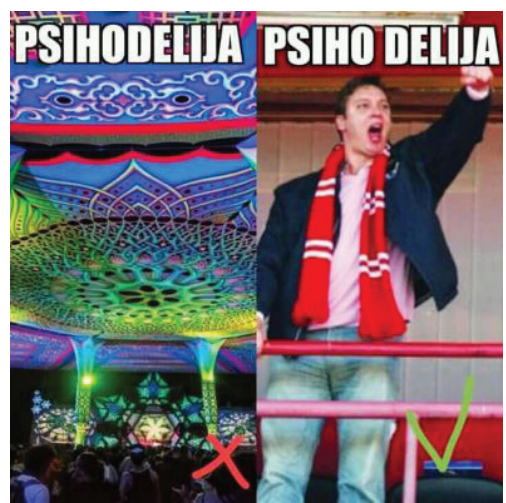

Slika 18. Meme. www.facebook.com 
U primjerima poput Flo Rida, umjetničkog imena američkog rappera, ili internetskih nadimaka poput San Dra, Dalibor Ka, Nenad Jebiv i Debi Lana adicijom se bjelina unutar postojećih vlastitih ili općih imenica (Sandra, Daliborka, nenadjebiv, debilana) konstruira kakav unikatan ili egzotičan pseudonim. S obzirom na to da se često rabe isključivo u pisanom kontekstu, kod takvih zapisa nije uvijek najjasnije podrazumijevaju li i pomaknut izgovor. Međutim za ime spomenutog rappera možemo biti sigurni da se izgovara različito od imena američke savezne države Floride, tj. kao [flou 'raidə].

Slika 19. Naslovnica singla Good Feeling glazbenog izvođača Flo Rida

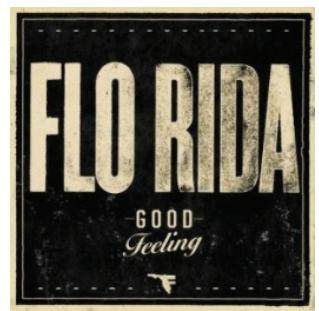

Poigravanja bjelinama, pa tako i njihova dodavanja, katkad se pojavljuju kao postupak u figurama namjernih pravopisnih pogrešaka, primjerice u nazivu satiričke Facebook-grupe tijedan polu pismenosti, u kojem se stiliziranje tih pogrešaka ostvaruje i supstitucijskom figurom slova (u $\langle$ tijedan $\rangle$, prihvati li se da je $\langle$ ije $\rangle$ alograf grafema $\left.\langle\langle\check{e}\rangle\rangle^{16}\right)$, ako ne i miniskulizacijom (malo slovo na početku naziva grupe). Adicijom bjelina dobiveno je i ime fikcijskoga lika Nepis mena, koje se pojavljuje na internetskoj ilustraciji anonimnog autora, kojom se uz sliku superjunaka s hrvatskom šahovnicom na prsima satirički aludira na ne tako rijetku pojavu problematične pismenosti u energičnijih domoljuba. ${ }^{17}$

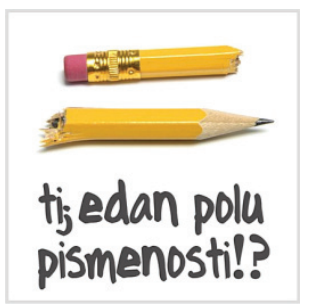

Slika 20. Profilna slika Facebook-grupe tijedan polu pismenosti. www.facebook.com

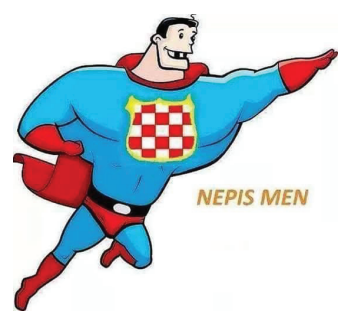

Slika 21. Ilustracija nepoznata autora. www.facebook.com

\footnotetext{
${ }_{16}$ Tako je primjerice u Ivan Marković, „O grafemu i hrvatskoj abecedi,“ Filologija 65 (2016): 77-112, odakle smo preuzeli i način bilježenja grafova i grafema posebnim tipom zagrada. ${ }_{17}$ Taj bi se primjer mogao tumačiti i kao osobita grafostopljenica riječi nepismen i men (prema engl. man 'čovjek'). Osobitost bi se te grafostopljenice sastojala u tome što se ostvaruje pomoću bjeline i grafodomestikacije. Više o grafostopljenicama u Nikola Košćak, „Grafička stapanja i grafostopljenice,“ Romanoslavica 52 (2016), 2: 275-289.
} 


\section{Suptrakcijske figure bjelina}

Slično jednom dijelu prethodno prikazanih adicijskih figura bjelina ni neka figurativna sastavljena pisanja nemaju neku osobitu konotaciju, odnosno percipiraju se tek kao dekorativna. Primjere takvih izostavljanja bjelina često nalazimo na naslovnicama glazbenih izdanja i u logotipima, primjerice u zapisu imena glazbenog sastava Mladi batali $^{18}$ (inače prethodnice poznatijeg splitskog Magazina), zapisu naziva albuma Noćna regata kao 〈NOĆNAREGATA〉 benda Regata i u pisanju imena dnevnika 24 sata kao 〈24sata〉 (redovito u samim novinama).

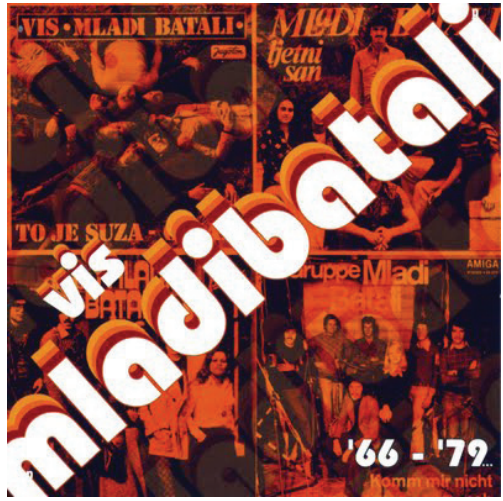

Slika 22. Naslovnica albuma Mladi batali glazbenog sastava Mladi batali. Fot. N. Košćak

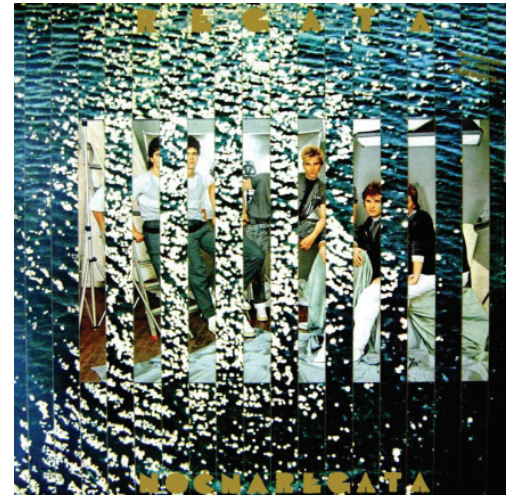

Slika 23. Naslovnica albuma Noćna regata glazbenog sastava Regata. Fot. N. Košćak

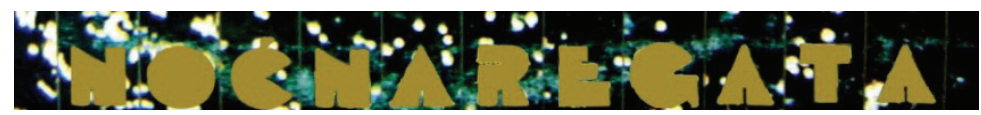

Slika 24. Naslovnica albuma Noćna regata glazbenog sastava Regata (detalj). Fot. N. Košćak

Takve su dekorativne suptrakcije bjelina još češće u zapisima na engleskom jeziku. Osobito se često na mnogim naslovnicama albuma višečlana imena izvođača ili naslova albuma pišu sastavljeno, kao u sljedećim slučajevima, no to svakako ne podrazumijeva i da su bendovi Talking Heads, Asian Dub Foundation, Darkwood Dub, Pearl Jam, Paradise Lost i Limp Bizkit tom prigodom promijenili ime ili da službeni naslov albuma Federica Aubelea nije Gran Hotel Buenos Aires:

\footnotetext{
${ }^{18}$ Batali su „neobrazovani stanovnici Splita koji nepravilno koriste hrvatski književni jezik“, prema članku Tonke Alujević „U nas bi se reklo... Koji si ti batal!,“ Slobodna Dalmacija, 12. lipnja 2012, pristupljeno 8. kolovoza 2020, https://www.slobodnadalmacija.hr/ dalmacija/split/clanak/id/169943/u-nas-bi-se-reklo-koji-si-ti-batal.
} 


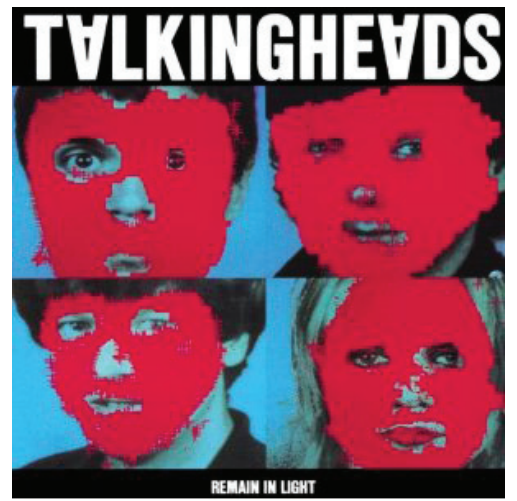

Slika 25. Naslovnica albuma Remain in Light glazbenog sastava Talking Heads. Fot. N. Košćak

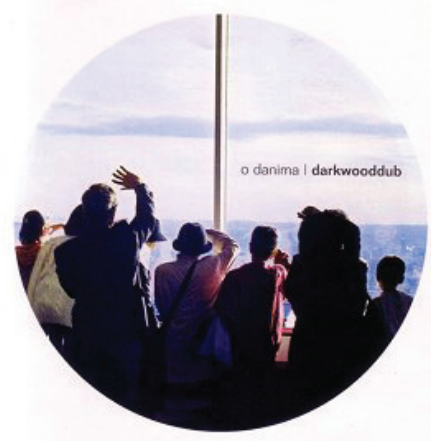

Slika 27. Naslovnica albuma $O$ danima glazbenog sastava Darkwood Dub. Fot. N. Košćak

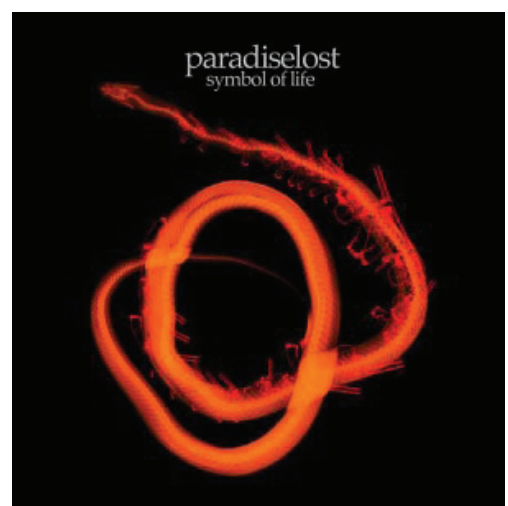

Slika 29. Naslovnica albuma Symbol of Life glazbenog sastava Paradise Lost. Fot. N. Košćak

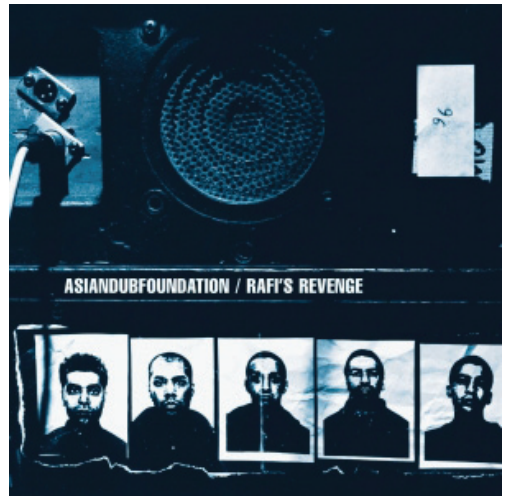

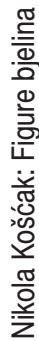

Slika 26. Naslovnica albuma Rafi's Revenge glazbenog sastava Asian Dub Foundation. Fot. N. Košćak

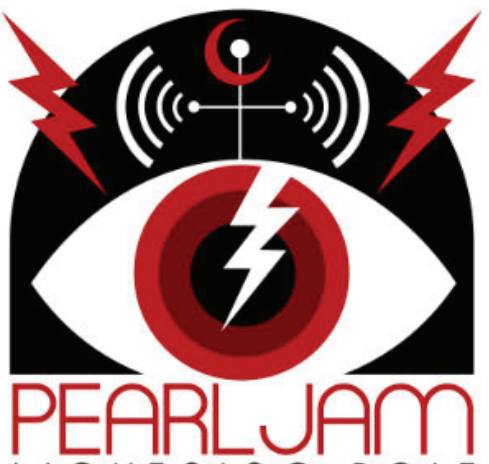

$L \mid G H T \cap I \cap G \quad B O L T$

Slika 28. Naslovnica albuma Lightning Bolt glazbenog sastava Pearl Jam. Fot. N. Košćak

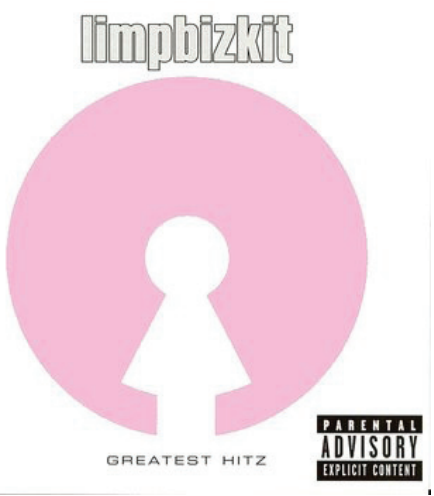

Slika 30. Naslovnica albuma Greatest Hitz glazbenog sastava Limp Bizkit. Fot. N. Košćak 


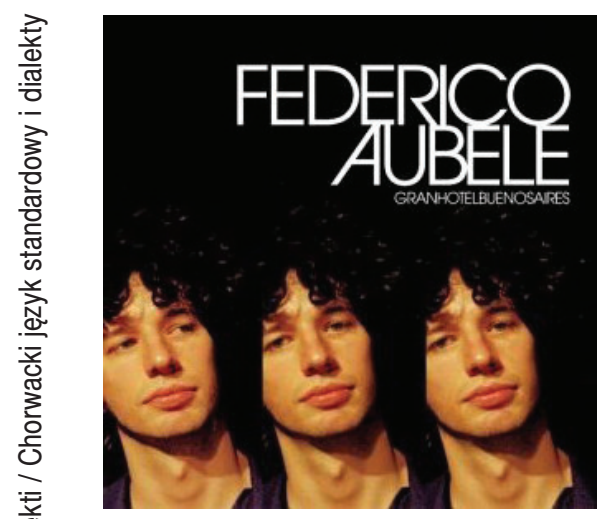

Slika 31. Naslovnica albuma Gran Hotel Buenos Aires Federica Aubelea. Fot. N. Košćak

Poput dodavanja i izostavljanje bjelina može biti motivirano značenjem jezične poruke ili konteksta, pa imati i metaforičku dimenziju. Tako zapis naslova albuma Endless Wire kao 〈ENDLESSWIRE〉 britanskoga benda The Who zahvaljujući suptrakciji razmaka između dviju riječi sintagme vizualno, pa i autoreferentno, predočava (goodmanovski: izražava) njezino značenje 'beskrajna žica'. Slično je i sa sloganom 〈Neprekidannizuspešnica.〉 u srbijanskoj reklami za TV-postaju $H B O$.

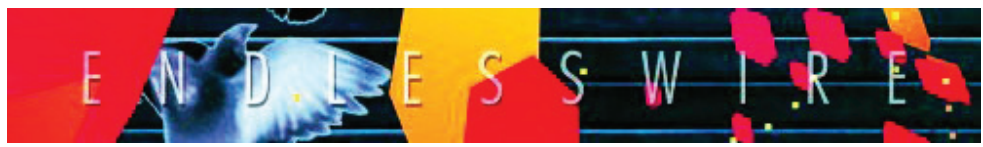

Slika 32. Naslovnica albuma Endeless Wire glazbenog sastava The Who (detalj). Fot. N. Košćak

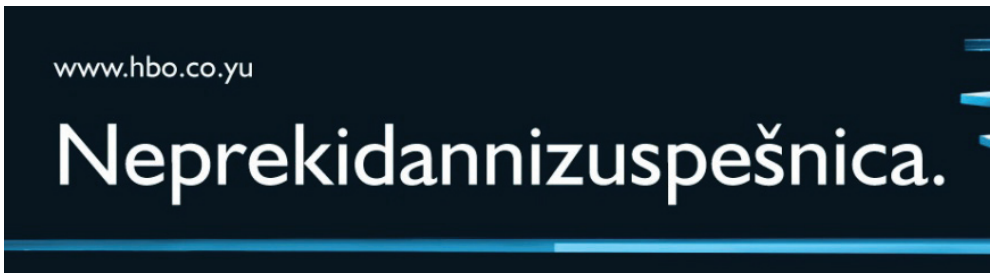

Slika 33. Reklama za $H B O$ (detalj). www.hbo.co.yu

Autoreferentnost se može detektirati i u načinu na koji je zapisano ime tvrtke svinaweb, gdje zapis evocira uobičajeno sastavljeno zapisivanje internetskih adresa, a internet je, kako je vidljivo iz njezina imena, domena tog pružatelja usluga koji se predstavlja kao marketing consultant.

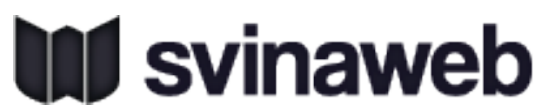

Slika 34. Logotip. https://svinaweb.hr/ 
Slično kao što se adicijom bjelina unutar postojeće riječi ona katkad „pretvori“ u bliskozvučan višerječni izraz, protupravopisno sastavljenim pisanjem može se sugerirati nastanak nove riječi, neologizam koji je produkt grafičkog spajanja sastavnica sintagme, čime se u pravilu očuđuje poznati izraz. Grafostilogeni neologizmi (a ti se grafostilemi ujedno mogu smatrati i leksikostilemima) prisutni su primjerice u pisanju nadimaka na internetskim forumima poput $\langle$ otompotom $\rangle$, a nalazimo ih i u književnim tekstovima:

„Kaeto?" reče na to on. ${ }^{19}$
Izmolio sam Anđelemojdragi ${ }^{20}$

Samo uska vrata, uzak stol, golemi ormar, na njemu velika lutka Bebakojaplače, pa krevet, nad krevetom nekoliko preostalih prastarih filmskih plakata, uglavnom vestern filmova. ${ }^{21}$

Stajali smo na trijemu hotela u predgrađu, pili kavu i pušili, Boro i ja. Jutro je bilo hladno, nasrtljivi sjeverac grizao je za lice i ruke, probijao do kostiju, no nismo imali izbora - hotel je bio neka pizdunska, zdravo tijelo, zdravomarijo, itakodalje ustanova. ${ }^{22}$

Zanimljiv primjer nalazimo i u zapisu 〈gdjećemo $\rangle$ u pjesmi $N j$ Zvonimira Baloga, kojim je upitna konstrukcija gdje ćemo suptrakcijom bjelina supstantivizirana, pretvorena u imenicu:

tako smo tražili

gdje ćemo

a gdjećemo

se bjelasalo u mraku sobe

čisto i nedirnuto ${ }^{23}$

Suptrakcije bjelina pojavljuju se često i u prozaičnijim memima koji, temeljeći se na relativnoj homografiji i homonimiji, čine svojevrsne grafoparafraze, vrlo često stihova iz popularne glazbe, kao kada se stih

${ }^{19}$ Ivan Slamnig, Sabrane pjesme (Zagreb: Grafički zavod Hrvatske, 1990), 405, bold N. K.

20 Slamnig, Sabrane pjesme, 182, bold N. K.

${ }^{21}$ Olja Savičević Ivančević, Adio kauboju (Zagreb: Algoritam, 2010), 15, bold N. K.

${ }^{22}$ Edo Popović, Tetovirane priče (Zagreb: Profil International, 2006), 19, bold N. K.

${ }^{23}$ Zvonimir Balog, Riba na biciklu. Pjesme (Zagreb: Znanje, 1977), 116, bold N. K. 


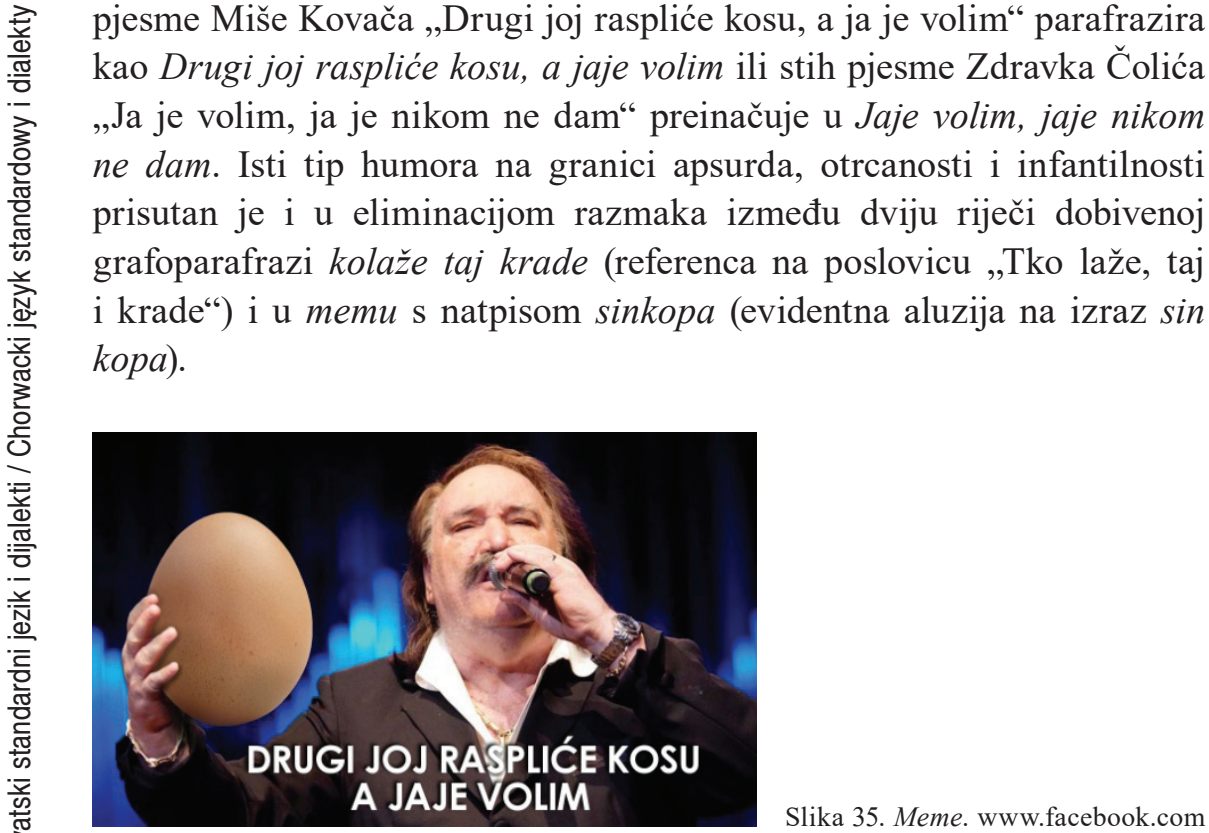

Slika 36. Meme. www. facebook.com

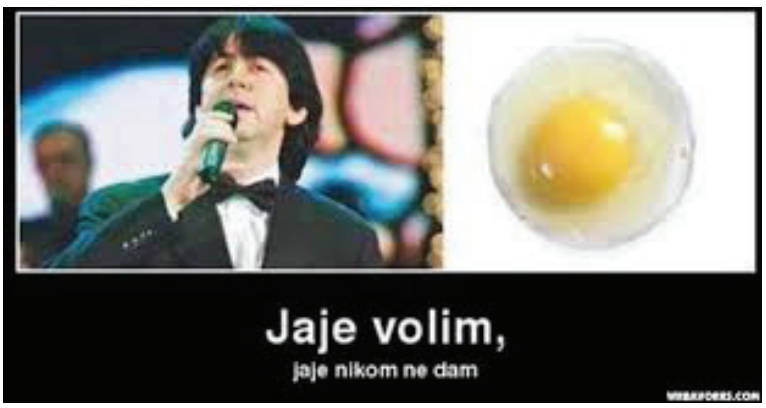

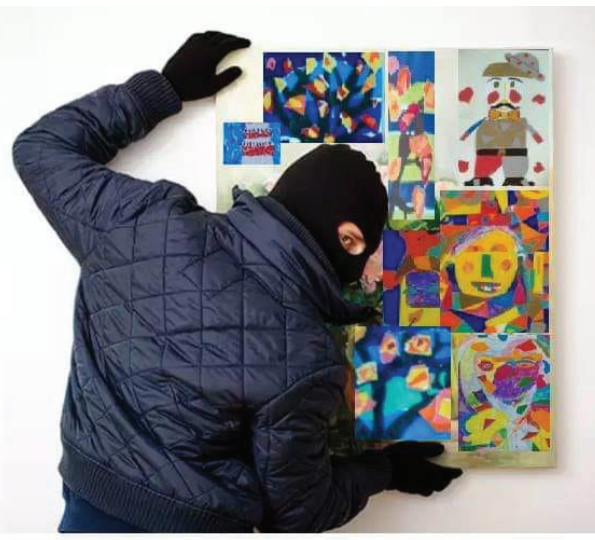

KOLAŽE TAJ KRADE

Slika 37. Meme. www.facebook.com

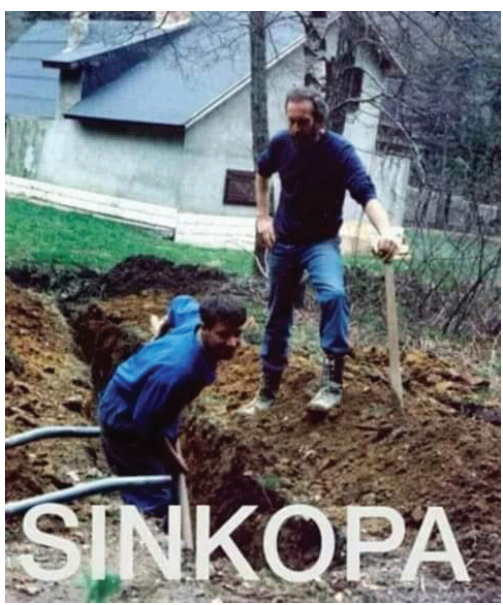

Slika 38. Meme. www.facebook.com 
Taj postupak nalazimo i u tipu viceva koji se temelje na zeugmi, ${ }^{24}$ uz dodatak djelomične homografije i homofonije, kao u primjeru Uđu dva vojnika u kupaonu. Jedan poručnik, drugi po sapun. ${ }^{25} \mathrm{U}$ takvim slučajevima moglo bi se govoriti i o grafozeugmi.

Bjeline između riječi katkad se izostavljaju i s intencijom (barem prividnog) eufemiziranja iskaza, kao u zagrebačkom grafitu 〈FREEDOM IS DOJAJA (pričem je intrigantno to što si autocenzuru nameće anonimni grafiter). Kao jedan od uspjelijih primjera izdvajamo logotip njujorškog muzeja seksa 〈museumofsex〉, koji na autocenzuru samosvjesno upućuje i boldanjem slova $\langle x\rangle$, inače oznake za sadržaje namijenjene isključivo odraslima.

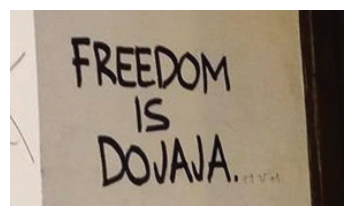

Slika 39. Grafit u Draškovićevoj ulici u Zagrebu. www.facebook.com

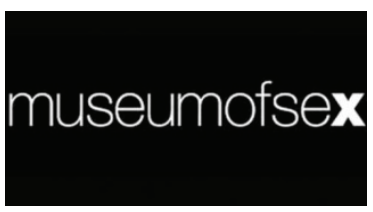

Slika 40. Logotip. www.museumofsex.com/

Eufemiziranje i autocenzuru detektiramo i u zapisu 〈Jebiga〉 na plakatu Dragana Kordića, koji poziva na promišljanje polisemičnosti tog popularnog kolokvijalnog izraza ${ }^{26}$ što ga je već uobičajeno vidjeti sastavljeno pisanog ne samo u privatnim porukama i na društvenim mrežama nego i u književnim tekstovima. Eufemiziranje primjećujemo i u zapisu 〈adamidash〉 s muške majice kratkih rukava u kojem se uz stiliziranje slova i fonta logotipa sportske marke Adidas suptrakcijska figura bjelina kombinira s grafoalijenacijom prikrivajući lascivan upit A da mi daš?. ${ }^{27}$

\footnotetext{
${ }^{24}$ Zeugma se definira kao ,[p]ostupak oblikovanja rečenice koji se sastoji u tome da se istom riječju - jezgrenim pojmom - poveže više riječi, sintagmi ili ishodišnih rečenica“ (Bagić, Rječnik stilskih figura, 315). Kao primjer neka posluži Bolje izdati ploču nego prijatelja, naslov singl-ploče KUD Idijota iz 1987. godine. Među poznatijim je vicevima onaj Dvije žene u rodilistu, jedna rađa, druga Kukoč.

${ }^{25}$ Spomenuti iskaz može se tumačiti kao zeugma u kojoj je jezgreni pojam ući u kupaonu, koji se povezuje s izrazima vojnik poručnik (subjekt) i vojnik po sapun (subjekt i objekt).

${ }^{26}$ Poruka se plakata na portalu Vizkultura eksplicira na sljedeći način: Jebiga je najveće izvini, kada se kaže tiho, i suosjećanje kada se kaže tiše. Jebiga je utješna nagrada, zagorjela palačinka, mokre noge, probušena guma i kratak kabel. Jebiga je psihoterapeut. Jebiga je način da izneseš loš dan, ali nije pasivni stav. Jebiga bi (obično) trebao slijediti osmijeh. Jebiga je krenuti iz početka bez gorkog, pristupljeno 8. kolovoza 2020, http://vizkultura.hr/ jebiga-red-je/.

${ }^{27}$ Potonji se zapis može tumačiti i kao osobito grafičko stapanje riječi Adidas i iskaza $a d a$ mi daš.
} 


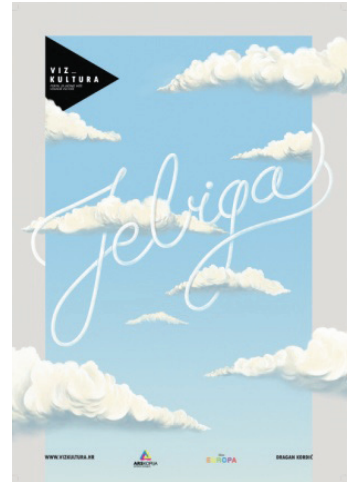

Slika 41. Plakat Dragana Kordića. http:// vizkultura.hr/jebiga-red-je/

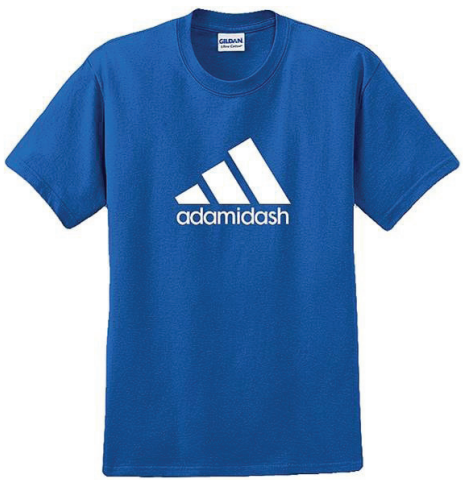

Slika 42. Majica adamidash. https://www.idealno. rs/Proizvod/2615366/nesortirano/nesortirano-ostalo/ ostalo-nesortirano/adamidash-majica-323

Figurativne suptrakcije bjelina pojavljuju se i kao jedan od postupaka grafostilizacije govor(e)nog jezika, kojim se najčešće reprezentiraju naglasne cjeline ili barem dijelovi naglasnih cjelina veći od riječi. Kao primjeri mogu poslužiti i gore komentiran natpis 〈Jebiga〉 i ime hrvatske dizajnerske marke Božesačuvaj (naziv nastao prema frazeologiziranom izrazu Bože sačuvaj! u kojem se zarez iza vokativa prema pravopisu i ne mora pisati ${ }^{28}$ ), a mnoštvo ilustracija nalazimo i u pisanoj internetskoj komunikaciji, tj. na društvenim mrežama te u suvremenoj kolokvijaliziranoj i žargonskoj proznoj književnosti. ${ }^{29}$

Ima i primjera osebujnijih funkcija izostavljanja bjelina. Tako je Zvonimir Balog ispisao cijelu jednu pjesmu suptrahiravši razmake između svih njezinih riječi. Fuzionirane riječi ${ }^{30}$ evidentna su satira na proklamiranu jednakost građana u jugoslavenskom socijalizmu, koja se ostvaruje ne samo providnom metaforom jednakosti svih vrsta riječi nego i grafičkim niveliranjem svih riječi u njoj: ${ }^{31}$

drugariceidrugoviimeniceglagolipridjeviveznicirazumijtevimeneoddanasmismosvijednoinematuvišetrtamrtaisraćkanjapotavanudostajebilotetakozvaneslobodetojestzajebancijeitomesličnonemavišejabiovojabionooddanassviodgovaramojednomnaslovu

\footnotetext{
28 V. Badurina, Marković, i Mićanović, Hrvatski pravopis, 59.

${ }^{29}$ Opširnije o tome u poglavlju „Grafostilistika žargonske i žargonizirane proze“ u Nikola Košćak, Šrajbenzi spiku? Stilovi hrvatske žargonske i žargonizirane proze 1990-ih i 2000ih (Zagreb: stilistika.org, 2018), pristupljeno 8. kolovoza 2020, https://stilistika.org/nikolakoscak-srajbenzi-spiku.

${ }^{30}$ Zvonimir Balog, Sklon disanju. Pjesme (Zagreb: Znanje, 1982), 104.

${ }^{31}$ Nikola Košćak, „Grafostilistika i poezija,“ u XIII. međunarodni kroatistički znanstveni skup. Zbornik radova, ur. Stjepan Blažetin (Pečuh: Znanstveni zavod Hrvata u Madžarskoj, 2017), 500.
} 
Recimo i to da suptrakcijske figure bjelina svakako treba razlikovati od kontinuiranog pisanja (scriptura continua) uobičajenog u starom i srednjem vijeku. $U$ tom kontekstu zanimljivo je istaknuti da

u svim suvremenim pisanjima uobičajeno rastavljeno pisanje riječi, odnosno uvrštavanje bjelina među njima, nema iznimno dugu povijest i nipošto nije ,pismovna univerzalija“. U zapadnoj se europskoj tradiciji neprekinut niz riječi, uspostavljen u grčkome uvrštavanjem vokala, počinje temeljitije narušavati tek od IX. ili X. st. (u karolinškim tekstovima), a gotovo posve normirano odvojeno pisanje riječi (pa i jednoslovnih, dvoslovnih i troslovnih) postiže se već potkraj XII. st. U istočnoj, bizantskoj (grčkoj), pismovnosti takvo razdvojeno pisanje postaje pravilnim tek u drugoj polovici XVI. st. ${ }^{32}$

$\mathrm{S}$ druge strane kontinuirano pisanje u suvremeno se doba snažno utvrdilo u digitalnom diskursu, i to u hashtagovima, oznakama koje počinju simbolom \#, a omogućuju grupiranje i lakše pronalaženje objava, tj. informacija u vezi s nekom temom na društvenim mrežama poput Twittera, Instagrama i Facebooka. Hashtagovi koji se sastoje od više riječi pišu se u pravilu bez bjelina (njih eventualno zamjenjuju velika početna slova svake od riječi u izrazu). Zbog njegove raširenosti i kodiranosti „heštegiranje“ smo međutim skloniji promatrati kao uzus digitalnog diskursa nego kao figurativan postupak, iako se među hashtagovima nađe i začudnijih (figurativnih) primjera, pogotovo kada se suptrakcija bjelina kombinira s drugim grafostilističkim postupcima, primjerice s onima koje zamjećuje Holjevac kao što su kapitalizacija, homonimijska numerizacija, adicija pravopisnih znakova, grafodomestikacija, majuskulizacija i dr. ${ }^{33}$

\section{Permutacijske figure bjelina}

Primjere permutacijskih figura bjelina nalazimo u memima koje komentira Holjevac ${ }^{34}$ - u popularnom pisanju izraza Vidimo se! kao 〈Vidim ose!〉 te u šaljivom premetanju izraza Crnoja je u 〈Crno jaje〉, koje autorica interpretira na sljedeći način:

\footnotetext{
${ }^{32}$ Mateo Žagar, Grafolingvistika srednjovjekovnih tekstova (Zagreb: Matica hrvatska, 2007), 300 .

${ }^{33}$ Holjevac, „Grafostilistika digitalnog diskursa.“

${ }^{34}$ Holjevac, „Grafostilistika digitalnog diskursa.“
} 


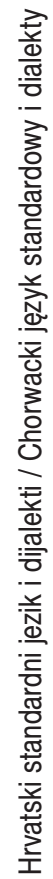

U [...] satiričnom prikazu [...] fiktivnog telefonskog razgovora između bivšeg premijera Ive Sanadera i bivšeg ministra branitelja Mije Crnoje, koji je tek nekoliko dana obnašao tu dužnost nakon formiranja nove vlade, prisutna je permutacija bjeline. Naime, ovaj grafostilistički postupak koji je naizgled nastao nenamjerno kao posljedica krivog dekodiranja poruke, izruguje ministra Crnoju čije je registrirano prebivalište bila trošna koliba, što je bila aktualna vijest danima. Na slici se bivši premijer Sanader, krivo razumjevši poruku, referira na poznati portal s grupnim popustima Crno jaje koji nudi razne jeftine smještaje. Grafostilističkim postupkom, odnosno permutacijom bjeline, postiže se sličnost između prezimena i imena portala, što je temelj za nastavak šale u kojoj Crnoja upravo svoju „trošnu“ kolibu nudi kao jeftin smještaj. ${ }^{35}$

Ah i to je došlo...doviđenja Ultra, Splite, Hajduče

i sa zadnjom slikom sa stadiona! Vidim ose!

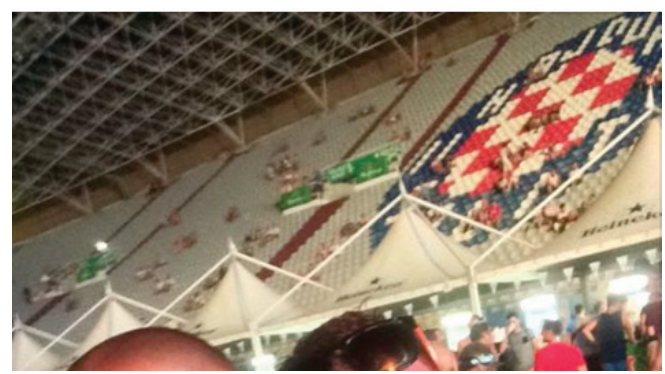

Slika 43. www.facebook.com

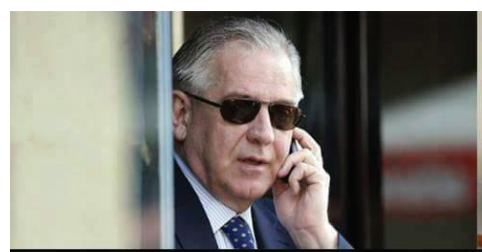

ALOI KOGA SAN DOBIA?
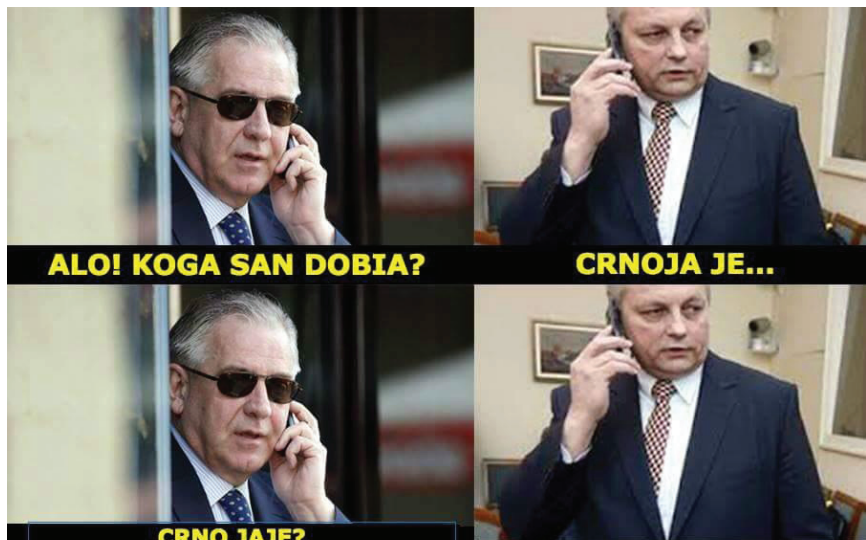

CRNO JAJE?

IMATE KAKAV JEFTINI SMJEŠTAJ?

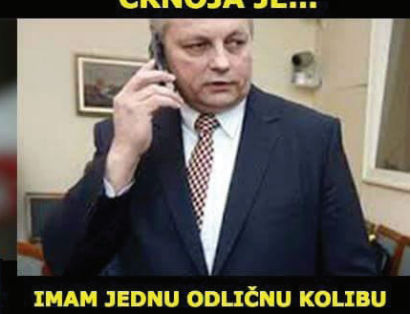

Slika 44. Meme. www.facebook.com

${ }^{35}$ Holjevac, „Grafostilistika digitalnog diskursa.“ 
Sljedeći vic, zabilježen na Facebook-stranici Apstraktni vicevi, poigrava se pak premetanjem bjelina u izrazu virus korona dolazi:

Bili turisti u Wuhanu na raftingu i spuštaju se čamcem, a vide nešto se kovitla u daljini. Pitaju skipera:

- Šta je ono?

Kaže skiper:

- Vir uskoro nadolazi.

Kao u prethodnim primjerima i u grafitu 〈ĐONTRA VOLTA $\rangle$ te u naslovu 〈Nikola Skejđ u „Game of Thrones“!??〉 bliskozvučnost i djelomična homografija motiviraju premetanje bjelina prema ishodišnim zapisima, ali uz grafodomesticiranje imena i prezimena poznatih američkih glumaca Johna Travolte i Nicholasa Cagea.

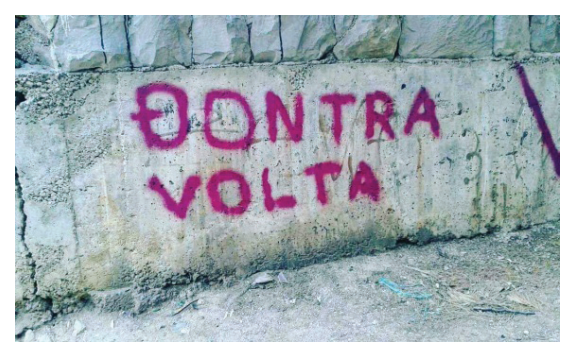

Slika 45. Grafit. www.facebook.com
Nikola Skejđ u "Game of Thrones"!??

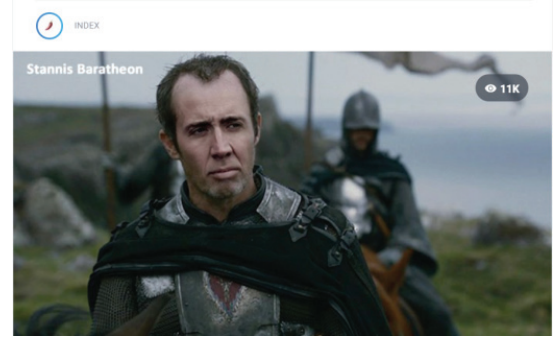

Slika 46. www.index.hr

\section{Supstitucijske figure bjelina}

Funkciju bjelina između riječi mogu preuzeti razni pismovni elementi, tipografska sredstva i dizajnerska rješenja. Tako u zapisu imena benda The Who kao 〈THEWHO〉 na već spomenutoj naslovnici albuma Endless Wire bjeline zamjenjuje razlika između standardnih i podebljanih (boldanih) slova istoga fonta. Taj tip supstitucije vrlo je čest, pogotovo kada se tako supstituira razmak između $d v i j u$ riječi, npr. u logotipima Zagrebačkog radija, Aquarius Music Shopa i internetske stranice Šalji dalje, na naslovnici albuma Šporke riči Petra Graše, u zapisima slogana 〈slobodnokuhaj〉 brenda Vegeta i 〈FOREVERFASTER〉 sportske marke Puma, u logotipu kampanje povodom referenduma za nezavisnost Škotske 〈bettertogether〉, u logotipima filmova The Rookie, The Imposter i The Prestige i dr. 


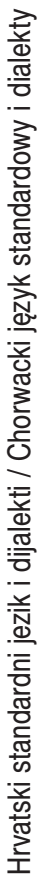

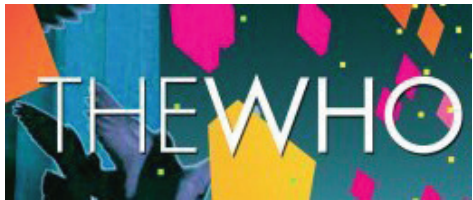

Slika 47. Naslovnica albuma Endeless Wire glazbenog sastava The Who (detalj). Fot. N. Košćak

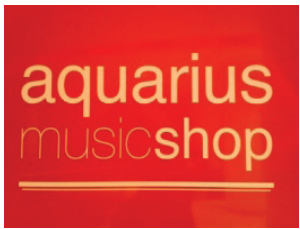

Slika 49. Logotip Aquarius Music Shopa. Fot. N. Košćak

\section{zagrebačkiradio \\ $99 \mathrm{MHz} 97 \mathrm{MHz}$}

Slika 48. Logotip. https://commons.wikimedia.org/wiki/File:Zagreba $\%$ C4\%8Dki radio_Logo_negative.svg

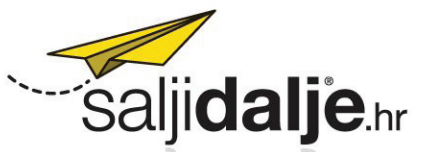

Slika 50. Logotip. www.saljidalje.hr

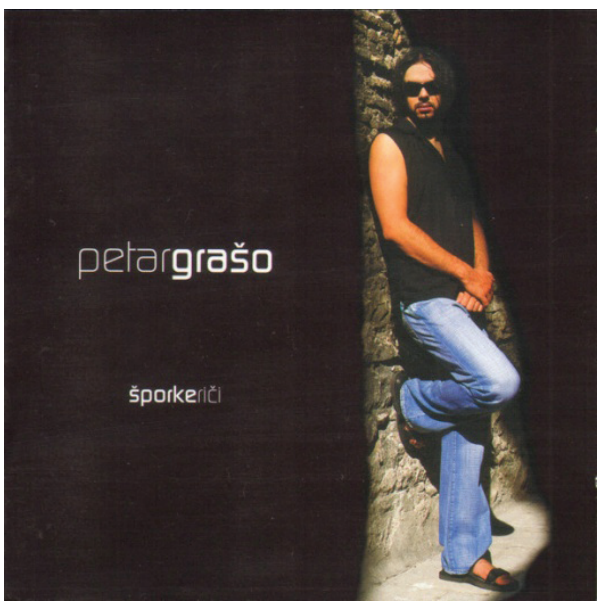

Slika 51. Naslovnica albuma Šporke riči Petra Graše. Fot. N. Košćak

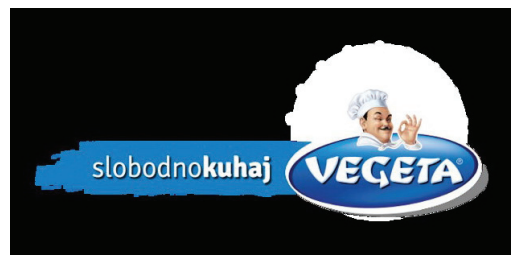

Slika 52. Reklamni slogan. www.vegeta.hr

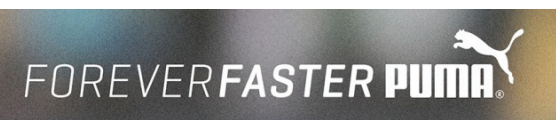

Slika 53. Reklamni slogan za sportsku marku Puma. Fot. N. Košćak 


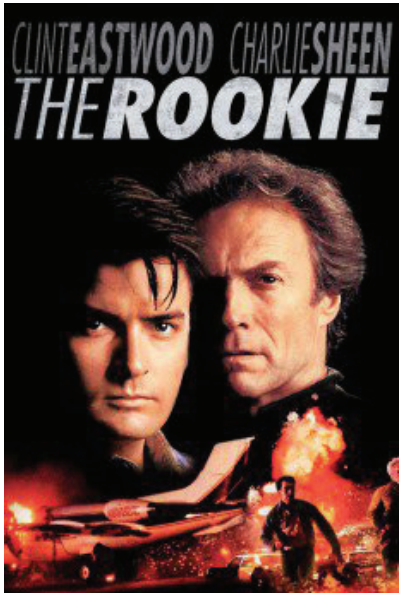

Slika 54. Plakat za film The Rookie. Fot. N. Košćak

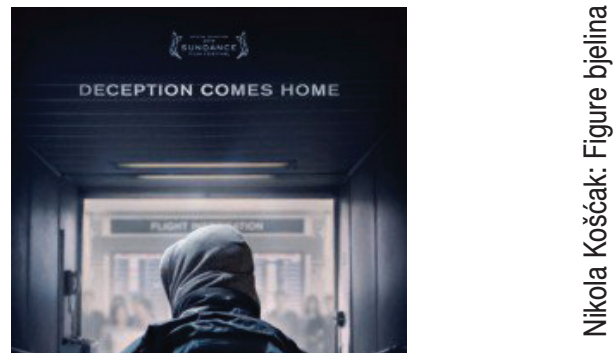

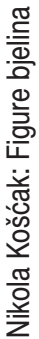

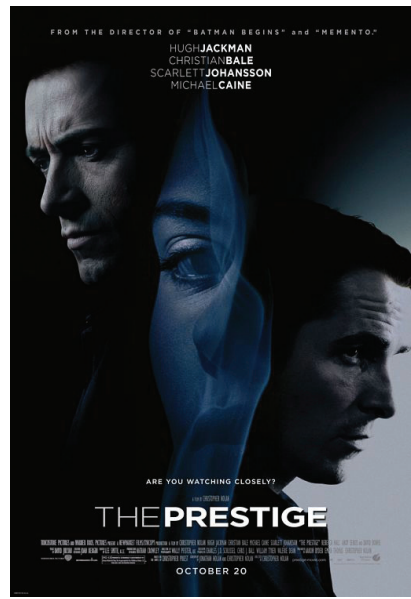

Slika 56. Plakat za film The Prestige. Fot. N. Košćak

Rjeđi su, a stoga često i začudniji, primjeri smjenjivanja normalnog i podebljanog tipa slova kojima se zamjenjuju bjeline između više riječi u nekom izrazu, kao u logotipima (internetske stranice) udruge Colorectal Cancer Association of Canada 〈getyourbuttseen.ca〉 i zeničkog Bosanskog narodnog pozorišta 〈bosanskonarodnopozorištezenica〉 ili na oglasnim materijalima za predstavu Buba u uhu kazališta Kerempuh ( $($ BUBAUUHU $\rangle)$. 


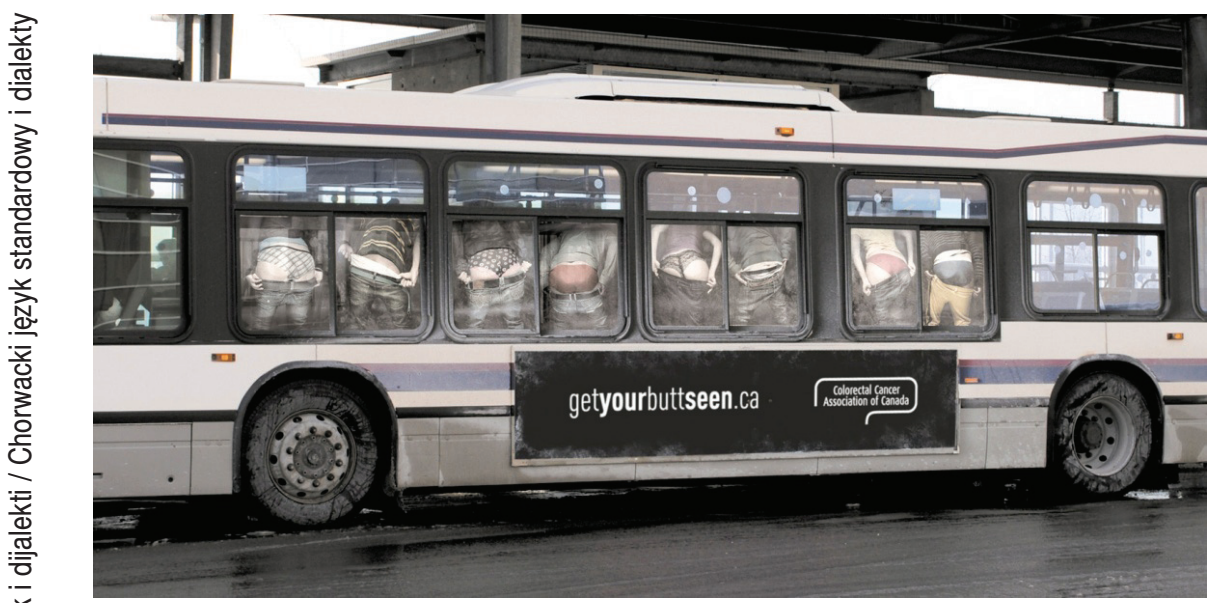

Slika 57. Logotip. http://ad-miration.blogspot.com/2011/03/got-feel-for-ambience-pt-8.html

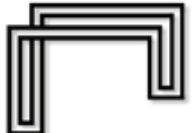

bosanskonarodnopozorištezenica

Slika 58. Logotip. www.bnp.ba

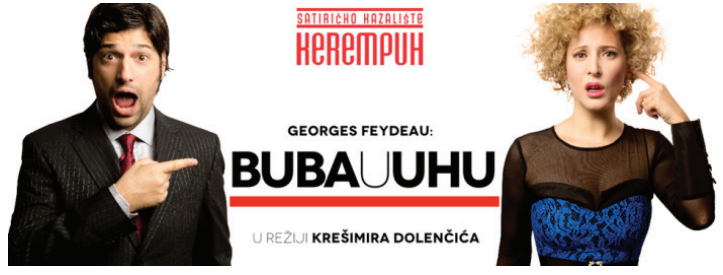

Slika 59. Reklama za kazališnu predstavu Buba $u$ uhu zagrebačkog kazališta Kerempuh https://kazalistekerempuh.hr/ predstave/buba-u-uhu/

Često i razlika u boji zapisa pojedinih riječi zamjenjuje bjelinu između njih, kao u zapisu KFC-ova slogana So good, u logotipima američke TV-serije Mad Men (kod nas prevedene kao Momci s Madisona), Splitske banke, Optima telekoma i udruga Selo pri ruci i Pravo na grad te internetskih stranica Trebam to i Van pameti, na naslovnicama albuma Bon Appetit glazbenog sastava Divas, Invocation sastava Šimun Matišić Sextet i Getz Plays Jobim: The Girl from Ipanema džez-saksofonista Stana Getza, u zapisima hrvatskih naslova američkih filmova Telefonska govornica (u originalu Phone Booth) i Oceanovih trinaest (Ocean's Thirteen) te u zapisu naslova predstave San Ivanjske noći kazališta Gavella:

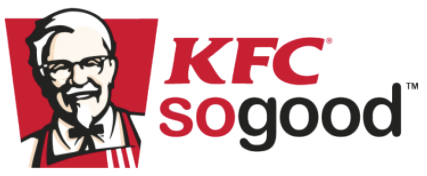

Slika 60. Logotip. kfc.com

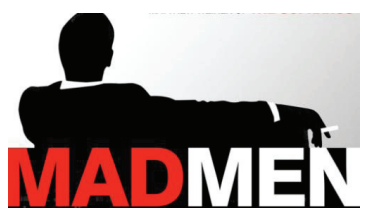

Slika 61. Logotip. https://www.amc.com/ shows/mad-men 


\section{splitskabanka}

Slika 62. Nekadašnji logotip Splitske banke. http://www.sloganini.com/s/698

Góptimatelekom

Slika 63. Logotip. www.optima.hr

\section{SELYOPRIRUCi} SEzONSKo-LOXaLNO-ParodNo-dostuPko wmw.selopriruci.org

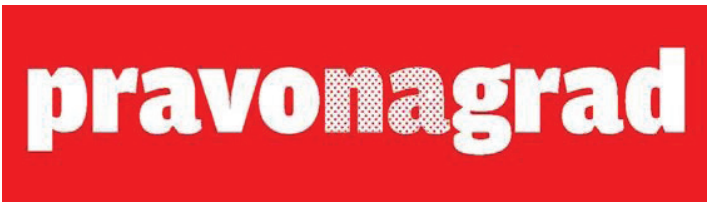

Slika 64. Logotip. www. Slika 65. Logotip. pravonagrad.org

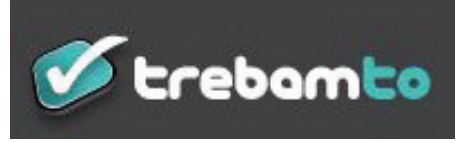

Slika 66. Logotip portala Trebam to. www.facebook.com

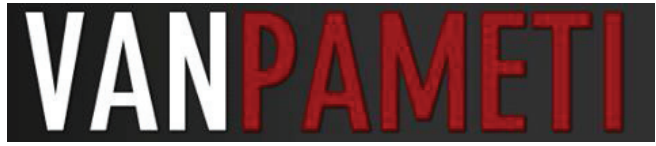

Slika 67. Logotip Facebook-stranice Van pameti. www. facebook.com

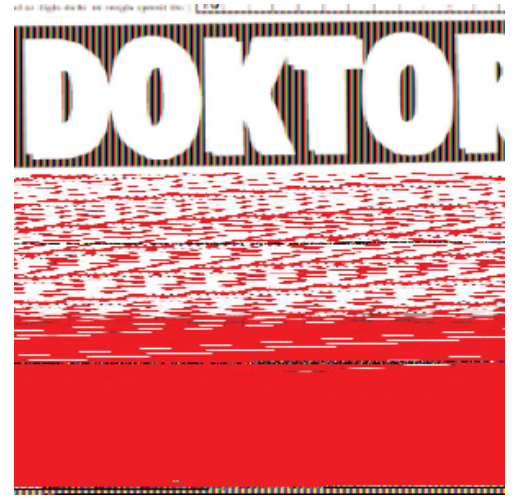

Slika 68. Naslovnica albuma Bon Appetit glazbenog sastava Divas. Fot. N. Košćak

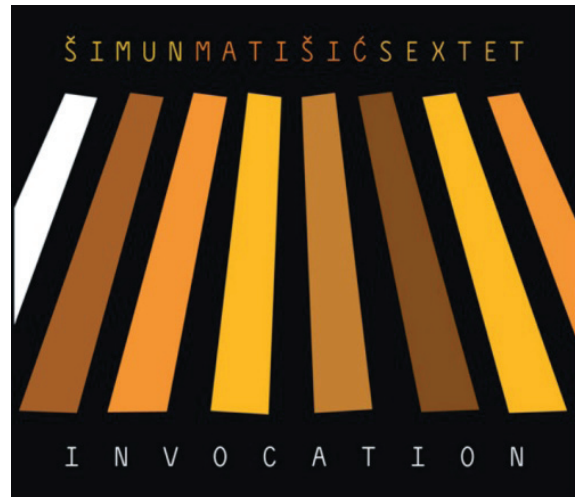

Slika 69. Naslovnica albuma Invocation glazbenog sastava Šimun Matišić Sextet. Fot. N. Košćak

Slika 70. Naslovnica albuma Getz Plays Jobim: The

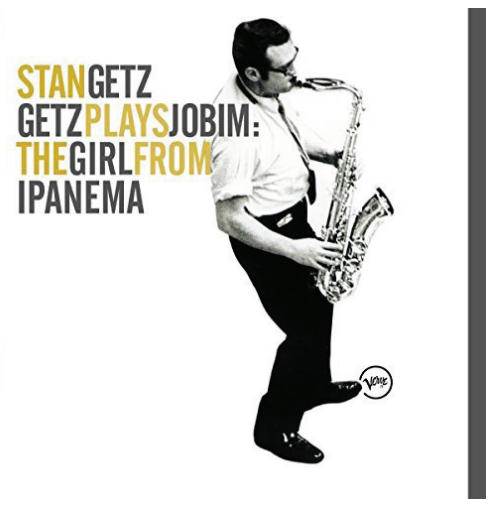

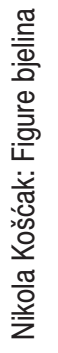



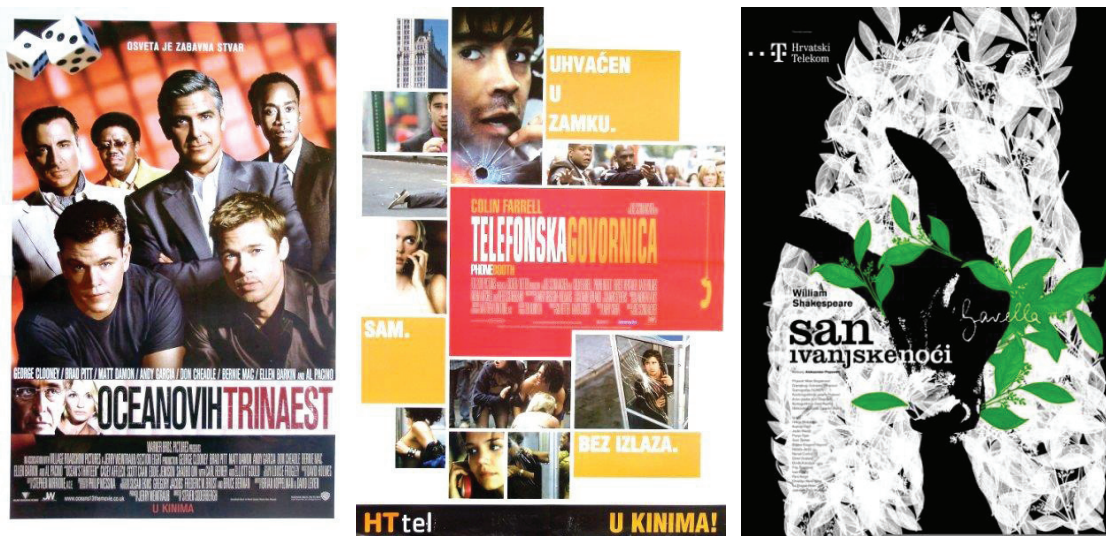

Slika 71. Plakat za film Ocea-Slika 72. Plakat za film Telefon-Slika 73. Plakat za kazališnu novih trinaest. Fot. N. Košćak ska govornica. Fot. N. Košćak predstavu San Ivanjske noći zagrebačkog kazališta Gavella

Funkciju bjeline katkad preuzimaju i velika početna slova (svih) riječi u zapisu, kao u logotipima internetske stranice Moj posao te časopisa Rolling Stone i Men's Health.

\section{MojPosao}

Slika 74. Logotip. www. Slika moj-posao.net

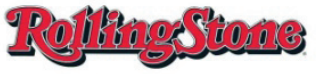

75. Logotip. rollingstone.com

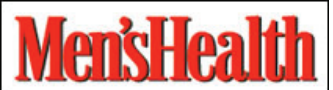

Slika 76. Logotip. www. menshealth.com

Donekle su tu funkciju preuzela i velika početna slova u logotipima benda Prljavo kazalište i Hrvatske lutrije (u kojima se bjeline između dviju riječi ipak naziru).

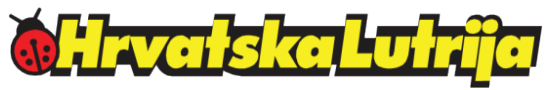

Slika 77. Logotip. www.lutrija.hr

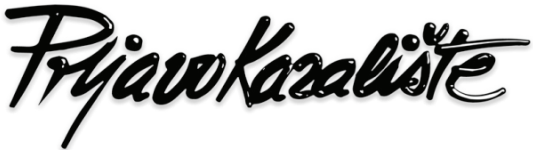

Slika 78. Logotip glazbenog sastava Prljavo kazalište. www.facebook.com

Razmak između riječi zamjenjuje se i razlikom između normalnog i kurzivnog tipa slova između dviju sastavnica sintagme, kao u logotipu proizvođača namještaja Perfecta Dreams (uz razliku u boji sastavnica). U logotipu pak internetske stranice Beer Advocate kurzivno prvo slovo druge riječi u sintagmi (također uz razliku u boji) zamjenjuje bjelinu između sastavnica sintagme.

\section{perfectadreams}

Slika 79. Logotip. perfecta.hr
Beeradvocate

Slika 80. Logotip. www.beeradvocate.com 
Razmak među riječima može se zamijeniti i razlikom majuskula/ minuskula u zapisima pojedinih sastavnica izraza, kao na plakatu za Automobilsko i motociklističko brdsko prvenstvo Jugoslavije iz 1949. godine, gdje razlika između majuskulnih pridjeva automobilsko i motociklističko te minuskulnoga veznika $i$ funkcionira kao signal bjeline. Isti tip zamjene nalazimo i na naslovnici albuma $M y$ Generation - The Very Best of The Who u zapisu imena glazbenog sastava The Who te na plakatima za američke filmove Phone Booth i The Rebound.

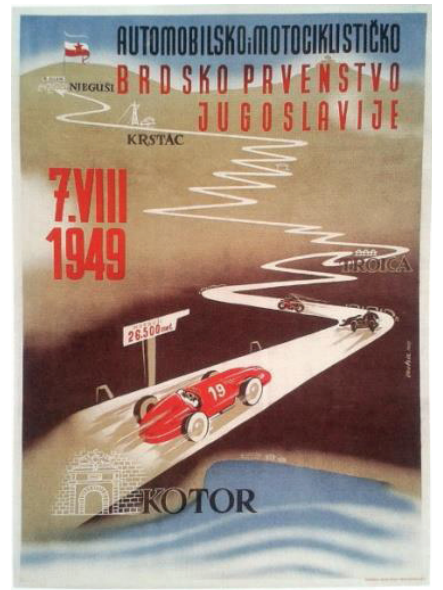

Slika 81. Plakat za Automobilsko i motociklističko brdsko prvenstvo Jugoslavije iz 1949. godine. Fot. N. Košćak

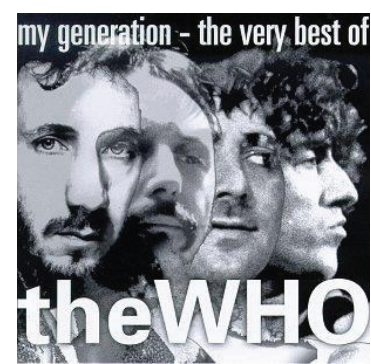

Slika 82. Naslovnica albuma My Generation - The Very Best of The Who glazbenog sastava The Who. Fot. N. Košćak

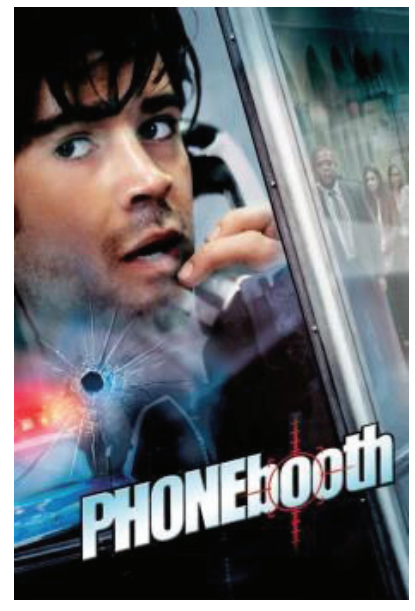

Slika 83. Plakat za film Phone Booth. Fot. N. Košćak

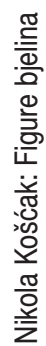




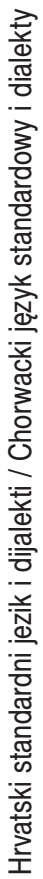

Isti je princip na djelu u logotipu zagrebačkog glazbenog festivala INmusic (uz poigravanje veličinama fonta pojedinih sastavnica i jednom zamjenom minuskulnoga $\langle i\rangle$ majuskulnim u riječi music).

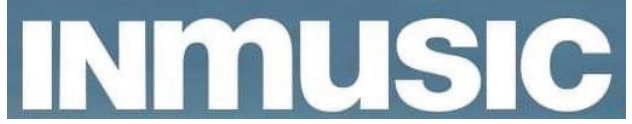

Slika 85. Logotip. www.inmusicfestival.com

I razlika u veličini slova katkad zamjenjuje bjeline, kao na hrvatskom plakatu za francuski film Djevojke u nevolji (Jeunes filles de Paris) iz 1936. godine, na plakatu za Sevdah u Lisinskom, gdje su manja slova zapisa prijedloga $u \mathrm{u}$ odnosu na veličinu slova u zapisu ostalih članova sintagme, u raznim verzijama logotipa američkog hip-hop sastava Cypress Hill i na plakatu za američki film The Firm (Tvrtka).

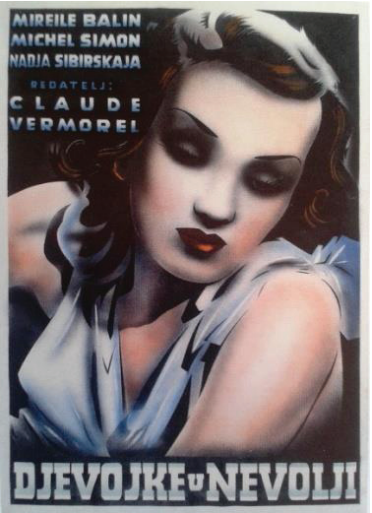

Slika 86. Plakat za film Djevojke u nevolji. Fot. N. Košćak

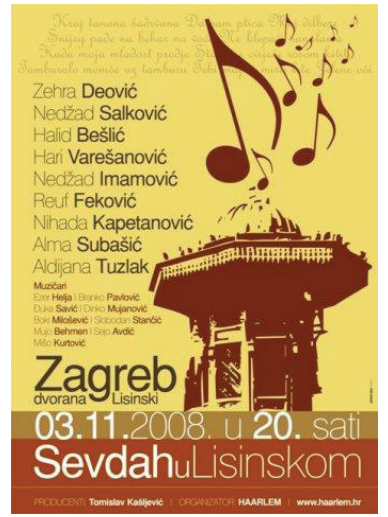

u Lisinskom. Fot. N. Košćak

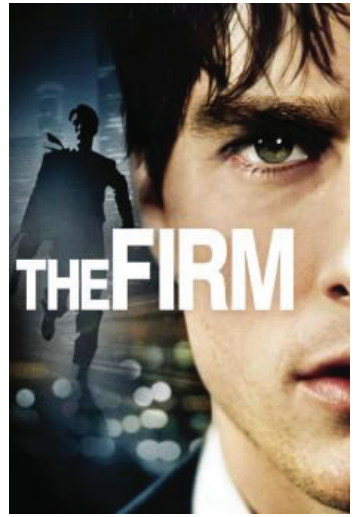

Slika 88. Plakat za film The Firm. Fot. N. Košćak

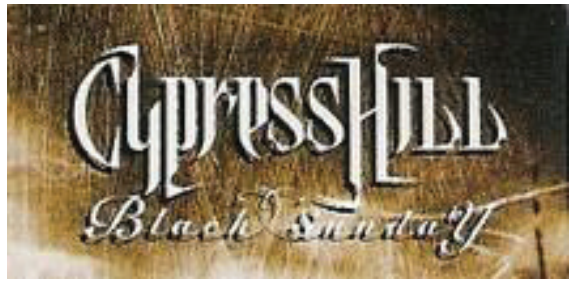

Slika 89. Naslovnica albuma Black Sunday glazbenog sastava Cypress Hill. Fot. N. Košćak

Takvu zamjenu nalazimo (doduše, uz naziranje bjelina) i u zapisu na jednom političkopromidžbenom plakatu iz razdoblja NDH: 
Slika 90. Plakat. Fot. N. Košćak

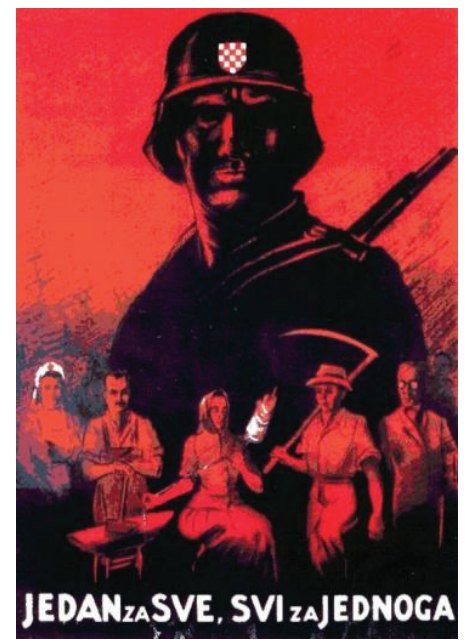

Funkciju bjelina katkad preuzimaju i razlike u fontovima između pojedinih riječi u zapisu, kao na naslovnici knjige Hrvatski politički plakat $1940-1950$ :

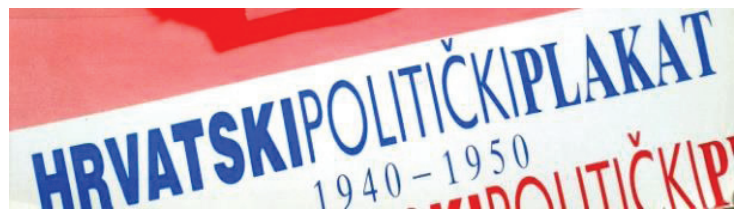

Slika 91. Naslovnica knjige Hrvatski politički plakat Snježane Pavičić (detalj). Fot. N. Košćak

Razmak između riječi može nadomjestiti čak i razlika između uobičajenih i ,zrcalnih“ slova, kao u logotipu časopisa Lice ulice / Lice u lice i na plakatu za predstavu Oko pola 1 kazališne družine Pinklec:

\section{LLICEUJIJ}

Slika 92. Logotip. www.liceulice.org

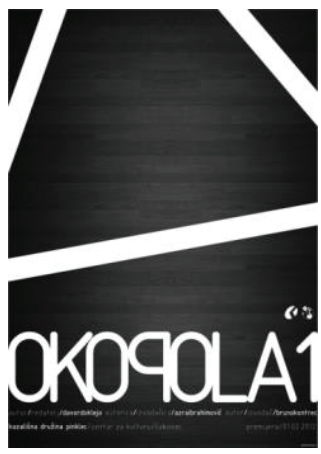

Slika 93. Plakat za predstavu Oko pola 1 kazališne družine Pinklec. Fot. N. Košćak 
Kako su neki prethodni primjeri već pokazali, katkad bjeline može zamijeniti i više pismovnih elemenata istodobno. Tako u logotipu $J u$ tarnjeg lista razmak zamjenjuju čak četiri razlike u elementima zapisa riječi jutarnji i list - razlika minuskula/majuskula te razlike $\mathrm{u}$ fontu, veličini i boji slova. I u logotipu mjesečnika Glas lova i ribolova bjeline između pojedinih riječi supstituirane su raznim sredstvima: između riječi glas i lova razlikom kurent/bold, a između riječi lova i $i$ te $i$ i ribolova razlikom u boji i fontu. Takva je višestrukost zamjenskih elemenata karakteristična i za logotipe aviokompanije American Airlines, TV-emisije inMagazin., englesko-američko-francuskog filma Love Actually, u zapisu imena benda Tonči \& Madre Badessa na naslovnici albuma The Best of, u zapisu imena i prezimena Mladena Grdovića na naslovnici albuma Samo more to zna, na naslovnici albuma Atomic američkog novovalnog benda Blondie, u zapisu slogana Upadni na INmusic i dr.

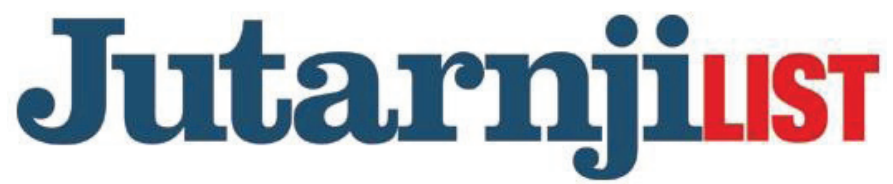

Slika 94. Logotip. www. jutarnji.hr

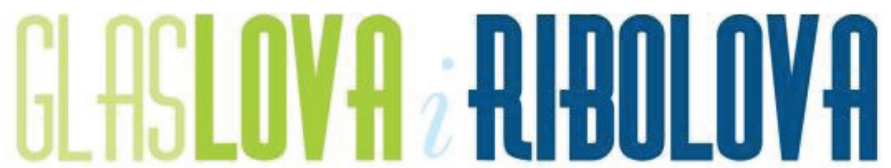

Slika 95. Logotip. www.glas-slavonije.hr/loviribolov/

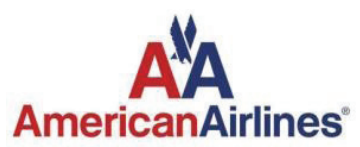

Slika 96. Logotip. www.aa.com

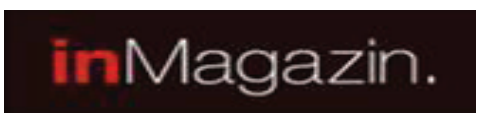

Slika 97. Logotip. https://novatv.dnevnik. hr/zabavni/in-magazin/

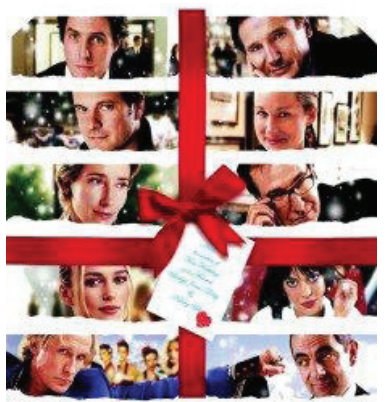

loveactually 

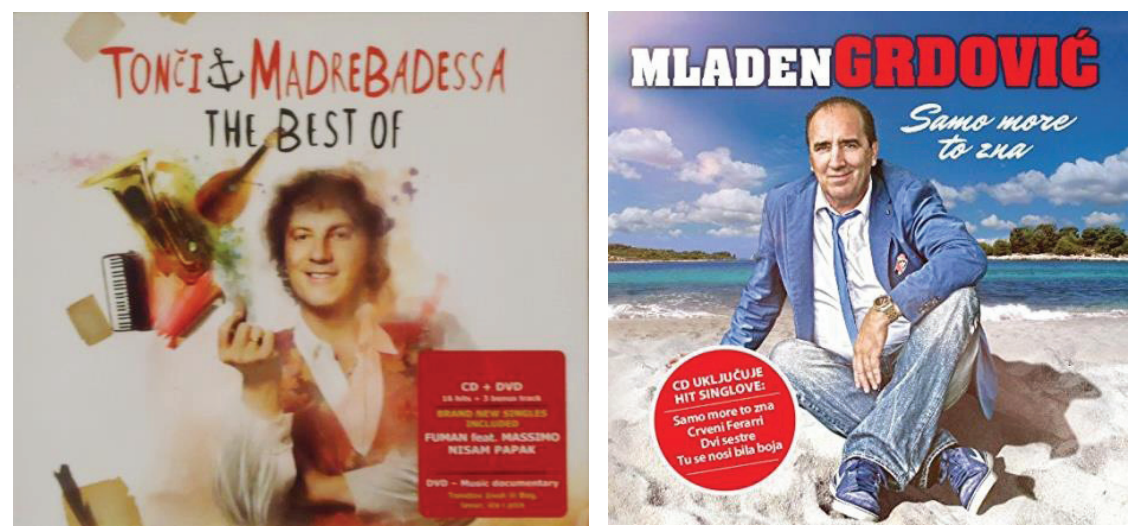

Slika 99. Naslovnica albuma The Best of glazbenog Slika 100. Naslovnica albuma Samo more to sastava Tonči \& Madre Badessa. Fot. N. Košćak zna Mladena Grdovića. Fot. N. Košćak
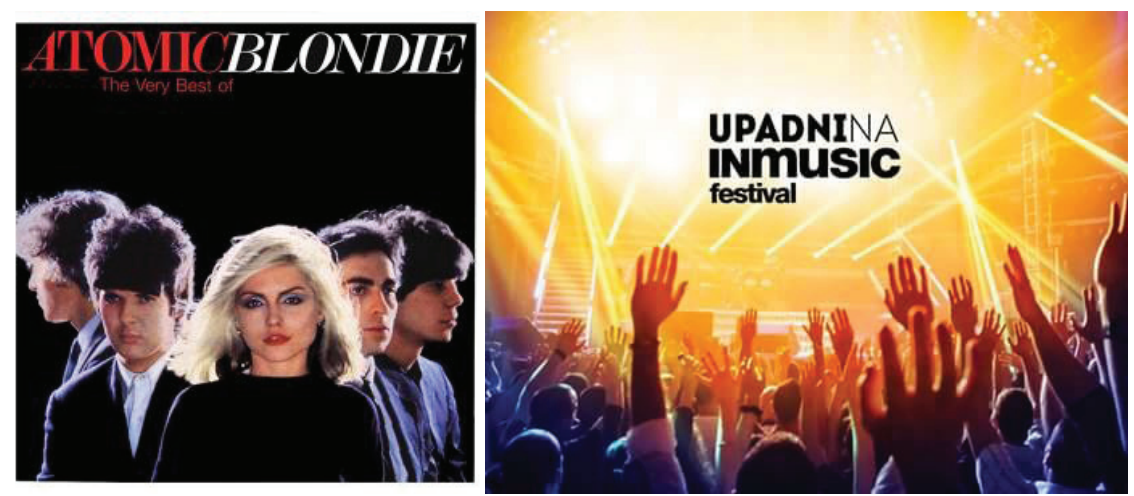

Slika 101. Naslovnica albuma Atomic Slika 102. Reklama. www.inmusicfestival.com glazbenog sastava Blondie. Fot. N. Košćak

U nekim pak zapisima nalazimo i pravopisne (i druge) znakove na mjestu bjelina, koji potonju možda toliko ne zamjenjuju koliko je ističu. Tako primjerice u logotipu 〈LOG.URBIS〉 arhitektonskog studija Log Urbis bjelinu supstituira, tj. ističe točka, a na naslovnici albuma Only by the Night benda Kings of Leon na dno retka položena crta:

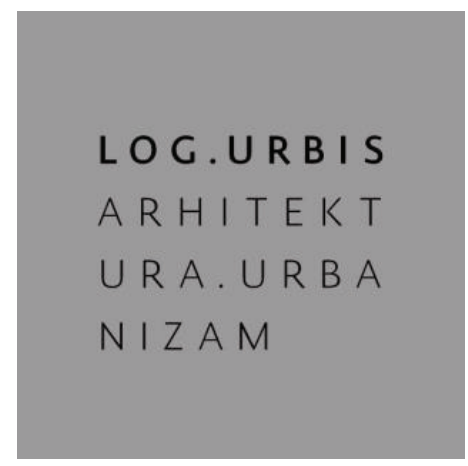

Slika 103. Logotip. www.log-urbis.hr
_KINGS_OF_LEON_- $\bullet\urcorner>$ ONLY_BY_THE_NIGHT >

Slika 104. Naslovnica albuma Only by the Night glazbenog sastava Kings of Leon (detalj). Fot. N. Košćak 


\section{Ekvivalencijske figure bjelina}

Ekvivalencijske figure bjelina uočavamo u slučajevima kada se u kakvom kontekstu pojavi kakva začudna jednakovrijednost u rasporedu bjelina, primjerice ponavljanje nekih tipova figura bjelina u manjem diskursnom prostoru. Evo nekoliko primjera takvih ponavljanja adicijskih figura bjelina. U sljedećem zapisu iz Feral Tribunea pojedine se riječi rastavljaju tako da evociraju kratice za titule. Razmicanje je ovdje $u$ funkciji prikazivanja ideološke srodnosti trojice političara:

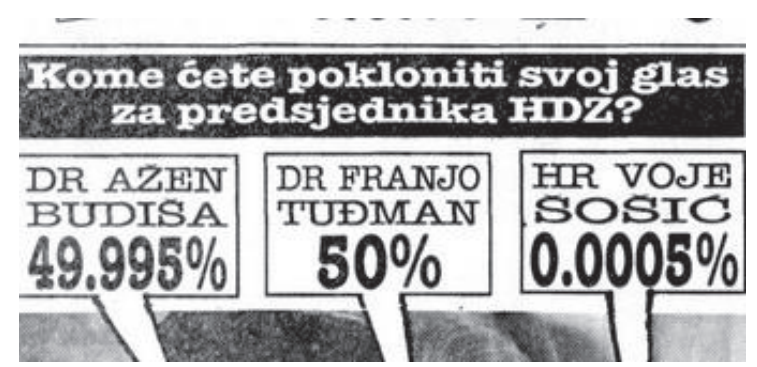

Slika 105. Feral Tribune, br. 419, str. 9.

U тети naslovljenom Zdravkometar, koji se poigrava djelomičnom homografijom i homonimijom imena Zdravko i frazema zdrav ko dren, ponavljanje postupka također čini ekvivalencijsku figuru bjelina.

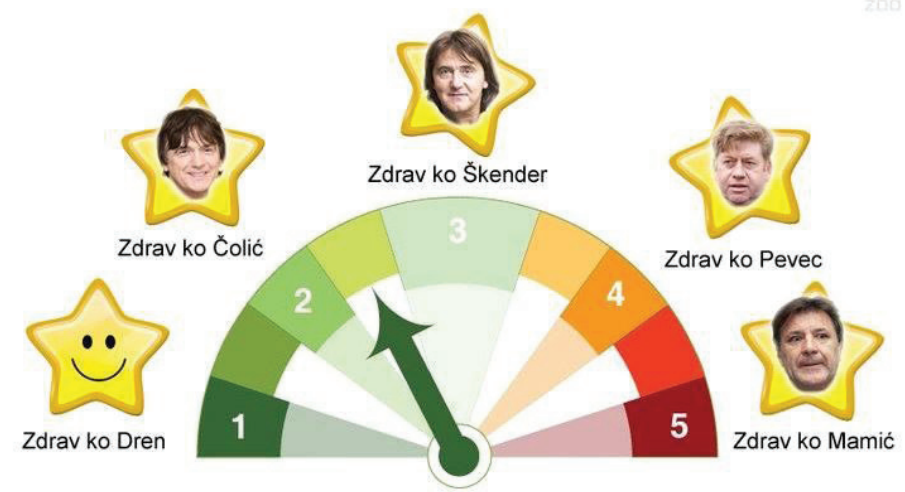

Zdravkometar

Koliko ste zdravi?

Slika 106. Meme. www.facebook.com

Kao što je već spomenuto, pojavljuju se gdjekad i figure intencionalnih ortografskih grešaka koje se poigravaju pravilima o sastavljenom i nesastavljenom pisanju riječi. Tako se u naslovu novinskog članka Bo- 
risa Dežulovića Ne mam pojma je li se piše dočim ili do čim ${ }^{36}$ implicitno ironiziraju nedoumice u vezi s pisanjem negacijskih oblika glagola htjeti (pa i one u vezi s pisanjem upitne konstrukcije je li). Zapis je ujedno i primjer ekvivalencijske figure: ekvivalencija se u tome naslovu s naglašenom metajezičnom funkcijom ostvaruje hotimičnim ponavljanjem protupravopisnog nesastavljenog pisanja riječi na početku i na kraju iskaza.

Zanimljiv primjer ekvivalencijske figure bjelina zamjećuje i Katarina Karević u svojem diplomskom radu o grafostilematici Balogova pjesništva u njegovoj pjesmi $A N A N A S .{ }^{37}$ Riječ je o jednoj od Balogovih pjesama koje se između ostalog poigravaju i elidiranjem za razumijevanje ključnog leksičkog materijala, gdje se ta figura ostvaruje repeticijom postupka kojim je riječ ananas rastavljena na manje značenjske jedinice: ${ }^{38}$

po pitanju ananasa stojimo znatno

A NA NAS kiša svako malo

A NA NAS uvijek misle kad

A NA NAS često viču bez

A NA NAS se bacaju sa

A NA NAS jedino tu i tamo

ANA NAS jedino tu i tamo

što je zANANAS sasvim

\section{Kombiniranje figura bjelina (i drugih figura zapisa)}

Figure bjelina katkad se i međusobno kombiniraju u istom zapisu, kao primjerice na naslovnici albuma Speaking in Tongues već spomenutog benda Talking Heads, gdje se i ime glazbenog sastava i naslov albuma zapisuju rastavljeni bjelinama unutar pojedinih riječi, ali se pritom pojedine riječi pišu i sastavljeno:

\footnotetext{
${ }^{36}$ Boris Dežulović, „Ne mam pojma je li se piše dočim ili do čim,“ tačno.net, 25. lipnja 2013, pristupljeno 8. kolovoza 2020, https://www.tacno.net/novosti/dezulovic-ne-mam-pojma-je-li-se-pise-docim-ili-do-cim/.

${ }^{37}$ Balog, Sklon disanju, 90.

${ }^{38}$ Katarina Karević, „Grafostilematika Balogova pjesništva i analiza govorne interpretacije odabranih pjesama“ (diplomski rad, Filozofski fakultet Sveučilišta u Zagrebu, 2018), 30.
} 


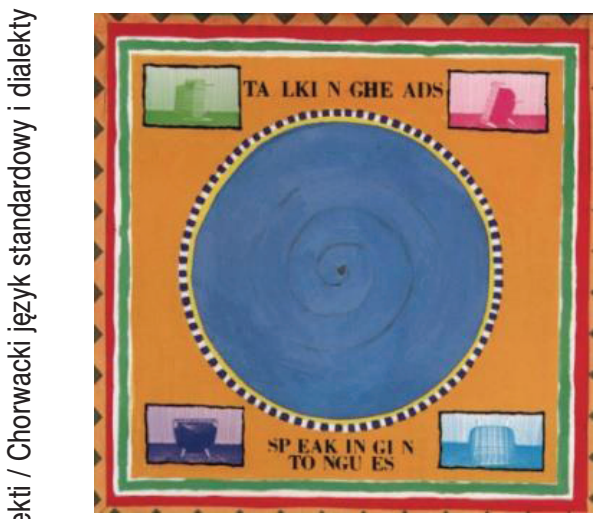

Slika 107. Naslovnica albuma Speaking in Tongues glazbenog sastava Talking Heads. Fot. N. Košćak

U sljedećem primjeru, nađenom na internetu, također se kombiniraju adicijske i suptrakcijske figure bjelina.

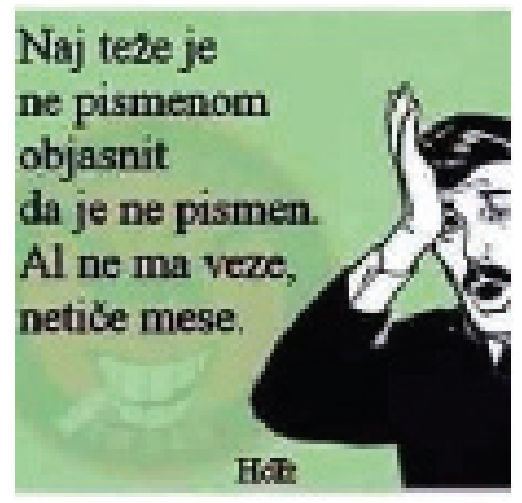

Slika 108. Meme. www.facebook.com

Primjer se čak čini podesnim za uvrštavanje u nastavnu jedinicu koja se bavi pravilima o sastavljenom i nesastavljenom pisanju, tim više što bi učenicima ili studentima mogao biti duhovit zbog svoje autoreferencijalnosti (nepismena maksima o pismenosti). Zanimljiva je pritom i dvostrukost smisla druge rečenice, to što se iskazivačeva rezignacija iz ugla implicitnog autora zapravo ironizira (,,da, njega se to doista ne tiče, niti bi ga se trebalo ticati kada već tako piše"). Raznim segmentima tog zapisa može se oprimjeriti nekoliko pravila o (ne)sastavljenom pisanju, npr. u vezi s pisanjem superlativnih i negacijskih prefiksa, niječnih čestica, atonalnih riječi i dr. ${ }^{39}$

U jednom poznatijem mетu bliskozvučnost i djelomična homografija motiviraju dodavanje i ispuštanje bjeline u izrazu usnula je iz stiha Tvoja mati usnula je pjesme Zora bila klape Intrade:

\footnotetext{
${ }^{39}$ Nikola Košćak, „Grafostilistika u nastavi hrvatskoga pravopisa,“ u Výuka jihoslovanských jazyků a literatur v dnešni Evropě III, ur. Elena Krejčová i Pavel Krejčí (Brno: Ústav slavistiky Filozofické fakulty Masarykovy univerzity, 2016), 181.
} 
Slika 109. Meme. www.facebook.com

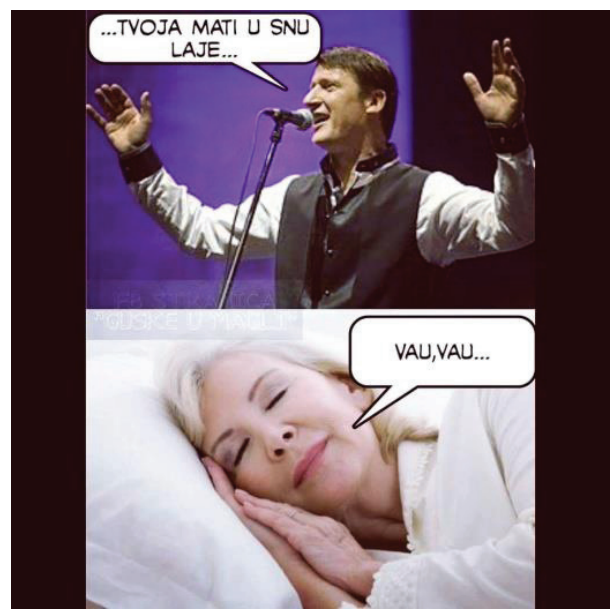

Kako je već uočeno pri komentiranju nekih zapisa u ovome poglavlju, figure bjelina katkad se kombiniraju i s drugim figurama zapisa, primjerice grafoalijenacijom (〈adamidash $\rangle$ ) i zamjenama normalnih slova podebljanim (〈museumofsex $\rangle$ ). Nalazimo i primjere kombinacija suptrakcijskih figura bjelina i slova - nekoliko zapisa u kojima se osim bjelina u višerječnim izrazima izostavljaju i slova, npr. registracijske oznake 〈DRTHVDR〉 i 〈BTCHPLZ〉, ,skrivaju“ izraze Darth Vader i Bitch, please, a na naslovnici albuma Exterminator ime glazbenog sastava Primal Scream zapisano je kao 〈PRMLSCRM〉.

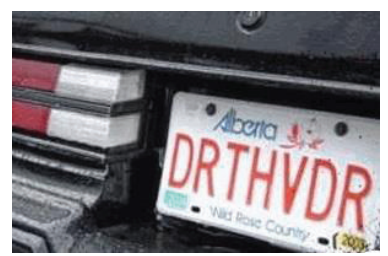

Slika 110. Fot. N. Košćak

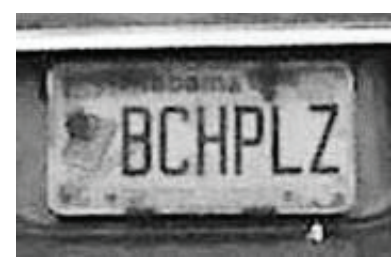

Slika 111. Fot. N. Košćak

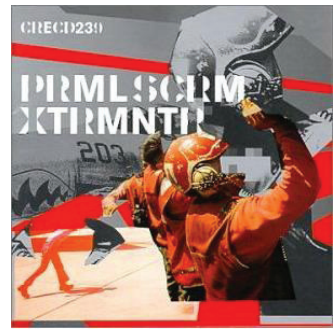

Slika 112. Naslovnica albuma Exterminator glazbenog sastava Primal Scream. Fot. N. Košćak

\section{Zaključci}

Iz ovoga pregleda vidljivo je da u tvorbi figura bjelina najčešće sudjeluju po dvije riječi (suptrakcijske, permutacijske, supstitucijske f. bjelina) ili jedna (adicijske f. bjeline), no nađeni su i primjeri s tri i više 
riječi. Najbrojniji su primjeri supstitucijskih, a najrjeđi permutacijskih i ekvivalencijskih figura bjelina. Figure bjelina najčešće se ostvaruju u logotipima, na naslovnicama glazbenih albuma, filmskim, kazališnim i koncertnim plakatima, u reklamama, memima, grafitima, novinskim naslovima i u sličnim kraćim diskursnim formama (žanrovima). Rjeđe su u književnosti (osim onih u funkciji reprezentacije naglasnih cjelina u grafostilizacijama kolokvijalnog jezika), što je, kako je već spomenuto u uvodu, zasigurno jedan od razloga zbog čega su takvi postupci dosad bili na marginama stilističkog i retoričkog interesa.

Dosadašnja marginalnost postupaka poigravanjem sastavljenim i nesastavljenim pisanjem u stilistici i retorici može biti i u vezi s time što oni često nemaju funkciju koja bi bila značajnija, tj. znakovitija od dekorativnosti, odnosno nastojanja da se privuče pozornost recipijenta. Ti su postupci naime rijetko semantizirani, tj. imaju nisku razinu konotativnosti, što je osobito uočljivo kod brojnih varijacija i primjera supstitucijskih figura bjelina. No ima i iznimaka: metaforičnost nekih adicija i suptrakcija bjelina, „derivacijska“ sastavljena pisanja, šaljivo simuliranje pravopisnih pogrešaka, upućivanje na pisanje internetskih adresa i dr. Osim u funkciji reprezentacije naglasnih cjelina, figure bjelina rijetko su i u relaciji s reprezentacijom akustičke dimenzije iskaza. Ipak, baš zbog izostanka potonje relacije, pa i onda kada je riječ o pukoj dekorativnosti, figure bjelina izvrsno oprimjeruju autonomnost nekih aspekata zapisa i upućuju na opravdanost govora o ,čistim“ figurama zapisa, odnosno na opravdanost zasebnog stilističkog proučavanja ovog područja što se svakodnevno napučuje sve većim brojem primjera. Ako među njima ima i podosta efemernih, to još uvijek ne znači da njihovo proučavanje ne može biti barem prilog potrebnom istraživanju efemernosti suvremene (pisane jezične) komunikacije.

\section{Literatura}

Alujević, Tonka. „U nas bi se reklo... Koji si ti batal!““ Slobodna Dalmacija, 12. lipnja 2012. Pristupljeno 8. kolovoza 2020. https://www.slobodnadalmacija.hr/ dalmacija/split/clanak/id/169943/u-nas-bi-se-reklo-koji-si-ti-batal.

Badurina, Lada, Ivan Marković, i Krešimir Mićanović. Hrvatski pravopis. Zagreb: Matica hrvatska, 2007.

Bagić, Krešimir. Rječnik stilskih figura. Zagreb: Školska knjiga, 2012.

Dežulović, Boris. „Ne mam pojma je li se piše dočim ili do čim.“ tačno.net, 25. lipnja 2013. Pristupljeno 8. kolovoza 2020. https://www.tacno.net/novosti/ dezulovic-ne-mam-pojma-je-li-se-pise-docim-ili-do-cim/. 
Holjevac, Rebeka. „Grafostilistika digitalnog diskursa.“ 27. siječnja 2017. Pristupljeno 8. kolovoza 2020. http://stilistika.org/studentski-kutak/diplomski-radovi/grafostilistika-digitalnog-diskursa.

Karević, Katarina. „Grafostilematika Balogova pjesništva i analiza govorne interpretacije odabranih pjesama.“ Diplomski rad, Filozofski fakultet Sveučilišta u Zagrebu, 2018.

Katnić-Bakaršić, Marina. Stilistika. Sarajevo: Ljiljan, 2007.

Košćak, Nikola. „Figure slova.“ U XII. međunarodni kroatistički znanstveni skup. Zbornik radova, uredio Stjepan Blažetin, 403-427. Pečuh: Znanstveni zavod Hrvata u Madžarskoj, 2015.

Košćak, Nikola. „Grafička stapanja i grafostopljenice.“ Romanoslavica 52 (2016), 2: 275-289. https://drive.google.com/file/d/0B_uQ9vm9C5K6b3JLcXRaRWczeXM/view.

Košćak, Nikola. „Grafostilistika u nastavi hrvatskoga pravopisa.“ U Výuka jihoslovanských jazyků a literatur v dnešní Evropě III, uredili Elena Krejčová i Pavel Krejčí, 173-181. Brno: Ústav slavistiky Filozofické fakulty Masarykovy univerzity, 2016.

Košćak, Nikola. „Grafostilistika i poezija.“ U XIII. međunarodni kroatistički znanstveni skup. Zbornik radova, uredio Stjepan Blažetin, 487-504. Pečuh: Znanstveni zavod Hrvata u Madžarskoj, 2017.

Košćak, Nikola. Šrajbenzi spiku? Stilovi hrvatske žargonske i žargonizirane proze 1990-ih i 2000-ih. Zagreb: stilistika.org, 2018. Pristupljeno 8. kolovoza 2020. https://stilistika.org/nikola-koscak-srajbenzi-spiku.

Košćak, Nikola. „Uvod u grafostilistiku. Figure zapisa.“ Skripta. Filozofski fakultet Sveučilišta u Zagrebu, 2018.

Marković, Ivan. „O grafemu i hrvatskoj abecedi.“ Filologija 65 (2016): 77-112. http://hrcak.srce.hr/154178.

Plett, Heinrich F. Textwissenschaft und Textanalyse: Semiotik, Linguistik, Rhetorik (Grundlagen der Sprachdidaktik). Heidelberg: Quelle \& Meyer, 1975.

Plett, Heinrich F. Literary Rhetoric. Concepts - Structures - Analyses. Leiden Boston: Brill, 2010.

Pranjić, Krunoslav. „Stil i stilistika.“ U Uvod u književnost: teorija, metodologija, uredili Zdenko Škreb i Ante Stamać, 253-302. Zagreb: Nakladni zavod Globus, 1983.

Žagar, Mateo. Grafolingvistika srednjovjekovnih tekstova. Zagreb: Matica hrvatska, 2007.

\section{Književni izvori}

Balog, Zvonimir. Riba na biciklu. Pjesme. Zagreb: Znanje, 1977.

Balog, Zvonimir. Sklon disanju. Pjesme. Zagreb: Znanje, 1982.

Popović, Edo. Tetovirane priče. Zagreb: Profil International, 2006.

Savičević Ivančević, Olja. Adio kauboju. Zagreb: Algoritam, 2010.

Slamnig, Ivan. Sabrane pjesme. Zagreb: Grafički zavod Hrvatske, 1990. 


\section{Figures of Spacing}

Summary: Stylistics and rhetoric have always neglected stylogenic procedures associated with the writing level of the language message, procedures based on manipulating the spacing between the words remaining peripheral even in one of the most elaborate overviews of the figures of writing, that of the German rhetorician H. F. Plett, who displays a series of procedures the basis of which is playing of graphemes (or graphs), punctuation and spelling signs. The method of this research will be inspired by the research of Plett, who divides and defines the graphemic figures (as he calls the processes known as figures of writing) by the addition, subtraction, permutation, substitution and equivalence of individual elements of the writing. According to these operations, five subtypes of these figures will be identified and exemplified: the addition, subtraction, permutation, substitution and equivalence figures of spacing, depending on whether any conventional record is modified by adding, omission or displacement of spacing, by replacing spacing with any other means of writing, or about whether any equivalence of the methods of manipulating the spacing between the word within a record is shown. The corpus consists of examples from the Croatian advertising, journalistic and literary discourse, also including examples from other contexts, in order to address the omnipresence of these figures in contemporary culture.

Keywords: graphostylistics, figures of writing, figures of spacing 